\title{
MONTANA GEOTHERMAL HANDBOOK
}

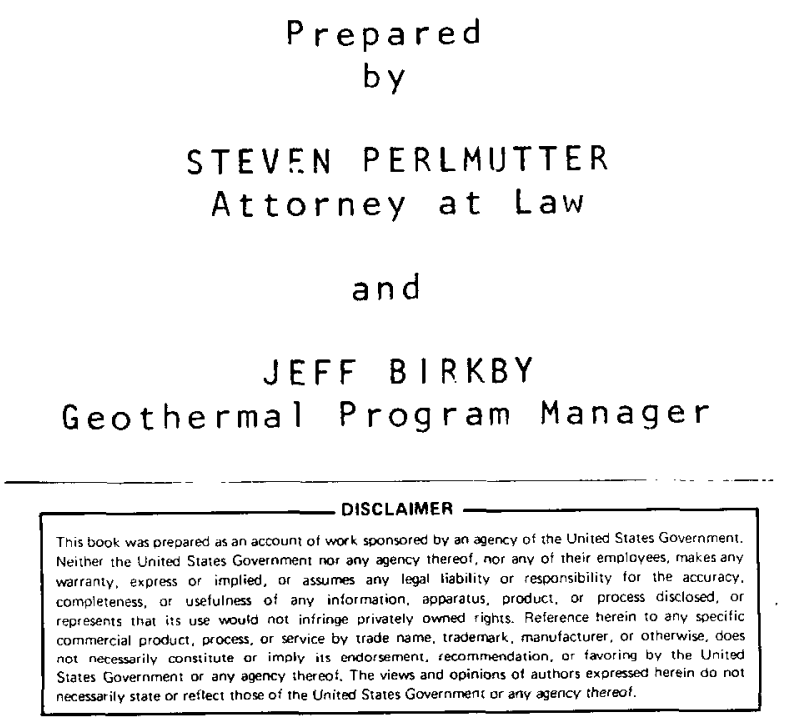

Published

by

Montana Department of Natural Resources and Conservation

Renewable Energy Bureau

Fall 1980

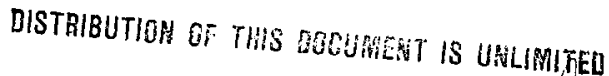




\section{DISCLAIMER}

This report was prepared as an account of work sponsored by an agency of the United States Government. Neither the United States Government nor any agency Thereof, nor any of their employees, makes any warranty, express or implied, or assumes any legal liability or responsibility for the accuracy, completeness, or usefulness of any information, apparatus, product, or process disclosed, or represents that its use would not infringe privately owned rights. Reference herein to any specific commercial product, process, or service by trade name, trademark, manufacturer, or otherwise does not necessarily constitute or imply its endorsement, recommendation, or favoring by the United States Government or any agency thereof. The views and opinions of authors expressed herein do not necessarily state or reflect those of the United States Government or any agency thereof. 


\section{DISCLAIMER}

Portions of this document may be illegible in electronic image products. Images are produced from the best available original document. 


\section{ACKNOWLEDGEMENTS}

This publication was funded cooperatively by the Montana Department of Natural Resources and Conservation and by the U.S. Department of Energy under Cooperative Agreement \#DE-FC07-79ID12014. Special thanks go to Karen

Renne for editing, Don Howard for cartography, and Carol Abrams for typing. 


\section{PREFACE}

\section{DNRC Geothermal Program}

The state of Montana, through the Department of Natural Resources and Conservation, is committed to developing geothermal energy to lessen our dependence on fossil fuel. In 1977 a state geothermal commercialization program began as a joint project between DNRC and the U.S. Department of Energy. The tasks of this program include:

1) Providing technical engineering assistance to geothermal resource owners (for space heating, greenhouse system design, etc.).

2) Identifying state and federal funding sources for geothermal projects.

3) Promoting legislation favorable to geothermal development.

4) Supporting research in the discovery and delineation of geothermal reservoirs.

In addition, the DNRC geothermal program staff keeps up-to-date information on current hot springs owners, advances in geothermal technology, and current geothermal research in Montana. A large collection of geothermal publications is available, including free brochures and sound/slide presentations that can be used by organizations throughout the state.

To request assistance from the DNRC Geothermal Program, call or write to:

Geothermal Program

Department of Natural Resources $\&$ Conservation

32 South Ewing

Helena, MT 59601

(406) $449-4624$ 
11. STATUTES AND REgULATIONS

1. RESOURCE OWNERSHIP ............... 10

2. LAND LEASING . . . . . . . . . . . . . . . 12

a. Federal Lands... . . . . . . . . . 12

b. Indian Lands ............. . . 16

c. State Lands . . . . . . . . . . . . 17

d. Local Government Lands . . . . . . . . . 20

e. Private Lands . . . . . . . . . . . . 21

3. EXPLORATION AND DEVELOPMENT

a. Federal Lands... . . . . . . . . . . 23

b. State Lands... . . . . . . . . . . 26

r. Seismic Exploration ............. 27

d. Well Drilling............... 28

e. Water Use Permit . . . . . . . . . 29

f. Public Water Supplies........... . 32

4. LAND USE REgULATIONS ................

a. Zoning ................ . . 34

b. Floodways and Floodplains.......... 35

c. Lakeshores . . . . . . . . . . 35

d. Streams and Streambeds . . . . . . . . 36

e. Erosion Control . . . . . . . . . . 38

f. Open Space and Natural Areas . . . . . . 39

g. Forests................. . . 39 


\section{FACILITY SITING}

a. The Major Facility Siting Act........ 40

b. Electric Generation on Federal Lands . . . . . . 44

6. ENVIRONMENTAL PROTECTION

a. Air Pollution Discharge Permit . . . . . . 46

b. Water Pollutant Discharge Permit . . . . . 48

c. Underground Injection Control........ 50

d. Environmental Impact Statements ....... 51

7. UTILITY EASEMENTS

a. Federal Lands................ 55

b. State Lands... . . . . . . . . . . 55

c. Local Agencies .............. . 56

d. Highway Right-of-Way . . . . . . . . . . 56

e. Private Lands and Eminent Domain . . . . . . 57

8. UTILITY REGULATION

a. Public Service Commission ... . . . . . 59

b. Utility Associations .............. 61

c. Rural Electric Cooperatives.......... 61

9. TAXATION

a. Federal Tax............... 63

b. State Property Tax ............ 63

c. State License Tax... . . . . . . . . . 64

d. New Industrial Property . . . . . . . . . 64

111. FUNDING OPPORTUNITIES

1. PUBLIC FUNDING

a. Improvement Districts........... 66 
b. General Obligation Bonds........... 68

c. Municipal Revenue Bonds . . . . . . . . . 68

d. Industrial Development Projects . . . . . . 69

2. LOAN, GRANTS AND INCENTIVES

a. The Geothermal Loan Guarantee Program ..... 70

b. Program Research and Development

Announcement (PRDA) .. . . . . . . 72

c. Program Opportunity Notice (PON)....... . 73

d. Appropriate Technology Small Grants . . . . . 74

e. Confirmation Drilling Program . . . . . . 76

f. Alcohol Fuels Program ........... 77

g. 0ld West Regional Commission Grants . . . . . 78

h. Coal-Impacted Community Grants ....... . 79

i. Alternative Renewable Energy Sources Program . . 81

j. Institutional Buildings Grants . . . . . . . 82

k. Tax Incentives............. 84

\section{APPENDIXES}

A. Addresses of State and Federal Agencies........ . 86

B. Legal Citations . . . . . . . . . . . . . . 89 


\section{INTRODUCTION}

Geothermal energy is an important energy resource throughout much of the western United States, including Montana. Development of this energy source, as with many other energy sources, may require state and federal permits from different agencies. Energy projects are sometimes delayed or even killed because the developer is not aware of the permits needed to develop a resource legally.

This handbook informs potential geothermal developers of the permits required on private, state and federal land in Montana, at each stage of development. Funding sources and tax incentives are also reviewed. The handbook is intended only as a guide for developers, not as a substitute for consultation with the appropriate federal, state and local agencies.

The regulatory path for geothermal development involves many agencies and permit review procedures. For a large project, such as an electrical generating plant, a minimum of five years should be scheduled between initial exploration and the commencement of production well drilling and plant construction. Another year or two may be necessary before actual operation will begin. For smaller, less complex projects (such as geothermal greenhouse or space heating) the total permitting process may take less than two years to complete.

For any project, it is essential that the developer make contact with the relevant agencies before starting development, maintaining regular contact throughout the process. This will help the agencies expedite whatever technical or environmental reviews are necessary, and may substantially decrease the time it takes to get a project into operation. 
The handbook is divided into three parts:

Part li: A list of the permits required for various geothermal projects, and the approximate time needed to obtain them.

Part lli: A brief discussion of the statutes and regulations referred to in Part I. This information was gathered in a survey of state and federall regulations, as wellil as, in conversations, with mumerous state and fiederal officicials.

Part lill: A description of some of the state and federal grant and loan programs, availablie to a prospective geothermall developer.

The names and addresses of the relievant state and federal agencies, appear in Appendix A. Legall citations are listed in Appendix B. 
I. LIST OF PERMITS 
Note: Each permit is discussed in the section of Part II noted in the left-hand column under "REFERENCE."

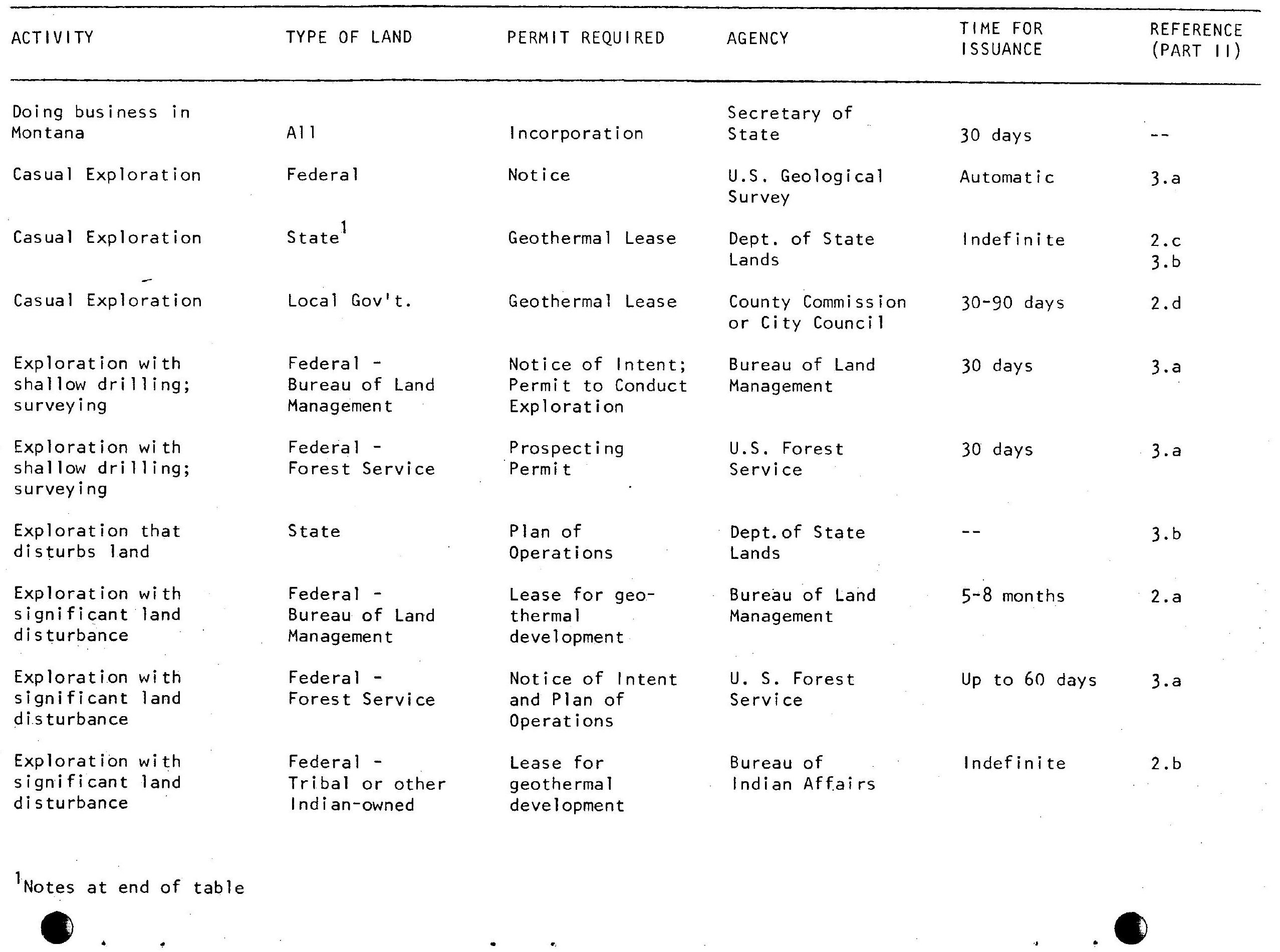


Al1

Seismic Exploration

Test Drilling

Exploration and Development

\section{Private --}

\section{Exploration and}

Development

Alteration of

or Lake or Shore

Alteration of

Stream or

Streambank

\section{Alteration of}

Navigable Stream

Stream Diversion

Exploration and

Development -

"Open Space" Area Zoned

Surety Bond

Permit for Geotion

All

Floodplain

Local Gov't or Private physical Explora-

Interim Water Use Permit and Longrange Plan

Land-use Permit

Secretary of

\section{State}

County Clerk and Recorder

Dept. of Natural

Resources and

Conservation

County Commission or City Council

Land-use Permit

County Commissign or City Council ${ }^{3}$

City Commission or City Council ${ }^{3}$

Soil \& Water Conservation District or County Commission

Dredge and $\mathrm{Fill}$ Permit

U.S. Army Corps of Engineers

Dept. of Fish, Wildlife and Parks

Approval

Consultation

County Commission
ISSUANCE

(PART II)

3. c

Automatic $c^{2}$

3. c

2-4 months

3.e

$5 . a$

$-$

4.a

Up to 60 days

4.b

Up to 90 days

4.c

Up to 60 days

4.d or City Council
Approx. 180

4.d

days

--

4.d

Indefinite

4. $f$ 


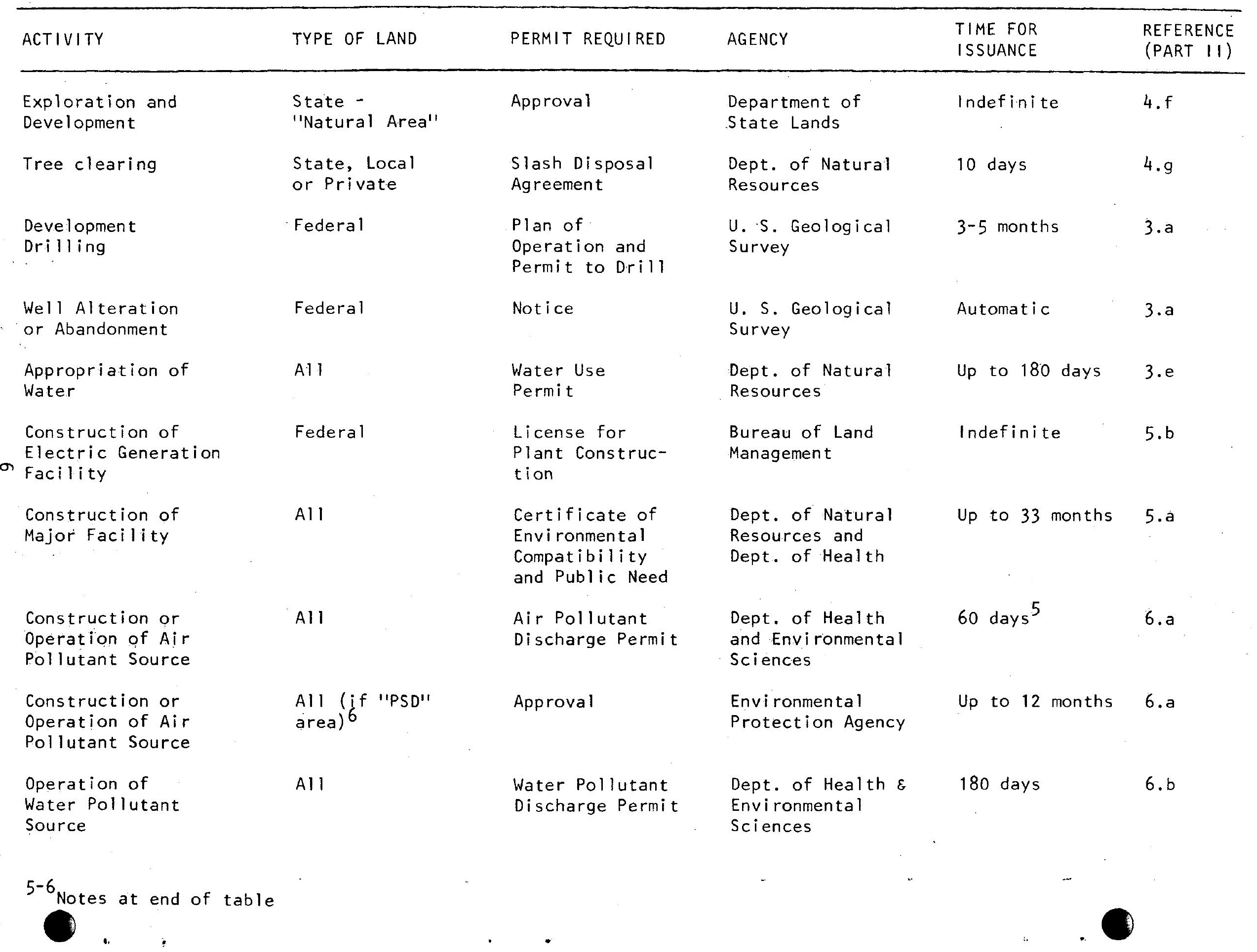




\begin{tabular}{|c|c|c|c|c|c|}
\hline ACTIVITY & TYPE OF LAND & PERMIT REQUIRED & AGENCY & $\begin{array}{l}\text { TIME FOR } \\
\text { ISSUANCE }\end{array}$ & $\begin{array}{l}\text { REFERENCE } \\
\text { (PART II) }\end{array}$ \\
\hline $\begin{array}{l}\text { Drilling } \\
\text { Reinjection Wells }\end{array}$ & All & $\begin{array}{l}\text { Underground } \\
\text { Injection Permit }\end{array}$ & $\begin{array}{l}\text { Environmental } \\
\text { Protection Agency }\end{array}$ & -- & $6 . c$ \\
\hline $\begin{array}{l}\text { Construction of } \\
\text { Pipelines or } \\
\text { Transmission } \\
\text { Lines }\end{array}$ & Federal & Easement & $\begin{array}{l}\text { Bureau of Land } \\
\text { Management or } \\
\text { Forest Service } \\
\text { or Bureau of } \\
\text { Indian Affairs }\end{array}$ & $1-3$ months & $7 . a$ \\
\hline $\begin{array}{l}\text { Construction of } \\
\text { pipelines or } \\
\text { Transmission } \\
\text { Lines }\end{array}$ & State & Easement & $\begin{array}{l}\text { Dept. of State } \\
\text { Lands or Dept. } \\
\text { of Natural } \\
\text { Resources }\end{array}$ & 45 days & $7 . b$ \\
\hline $\begin{array}{l}\text { Construction of } \\
\text { Pipelines or } \\
\text { Transmission } \\
\text { Lines }\end{array}$ & Local Gov't & Easement & $\begin{array}{l}\text { County Commission } \\
\text { or City Council }\end{array}$ & -- & $7 . \mathrm{c}$ \\
\hline $\begin{array}{l}\text { Construction of } \\
\text { Utility Lines } \\
\text { in Highway Right-of- } \\
\text { Way }\end{array}$ & State & Approval & $\begin{array}{l}\text { Department of } \\
\text { Highways }\end{array}$ & -- & $7 . d$ \\
\hline $\begin{array}{l}\text { Development, } \\
\text { Including Pipelines } \\
\text { and Transmission } \\
\text { Lines }\end{array}$ & Private & $\begin{array}{l}\text { Complaint for } \\
\text { Condemnation }\end{array}$ & District Court & -- & $7 . e$ \\
\hline $\begin{array}{l}\text { Sale of Heat or } \\
\text { Electricity }\end{array}$ & Al1 & Tariff Approval & $\begin{array}{l}\text { Public Service } \\
\text { Commission }\end{array}$ & Up to 9 months & $8 . a$ \\
\hline
\end{tabular}


${ }^{1}$ Includes school trust lands, beds of navigable waters, and other acquired lands, but not recreational lands or lands used by state institutions for public buildings, campus grounds, or experimental purposes. Geothermal leases must be negotiated with the appropriate state agency.

${ }^{2}$ The county clerk and recorder automatically issues a permit after the Secretary of State has certified the surety bond.

3 If the local governing agency has not adopted a permit procedure, application should be made to the Department of Natural Resources.

${ }^{4}$ Slash burning requires a state open burning permit from the local sheriff or sanitarian and approval by the local fire control official.

${ }^{5}$ The time for issuing the permit will be longer if an Environmental Impact Statement is required.

$\infty$ "'PSD" means that the ambient air quality in the region is currently better than national standards. Under these conditions, the Environmental Protection Agency is charged with "prevention of significant deterioration" (PSD). 
11. STATUTES AND REgULATIONS 


\section{RESOURCE OWNERSHIP}

Anyone who intends to explore, lease, or develop geothermal resources must first determine who owns them. Because geothermal resources are neither water nor mineral, entirely, this question seldom has a clear or easy answer.

The water-mineral issue is important primarily when the surface rights to land have been severed from the mineral rights. If geothermal resources are treated as water, they belong to the surface owner; if as mineral, they are part of the subsurface estate. Both state and federal law have made it clear that mineral reservations on state and federal land now include geothermal sources.

In most litigation involving past conveyances of federal mineral rights, the courts have treated geothermal resources as a mineral. The question has yet to be litigated in Montana. To be safe, a potential developer should secure both surface and mineral rights whenever possible. Furthermore, leases should include a "lessor interest" clause protecting the developer in case it turns out that his lessor does not actually own what he thought he did.

Another question is: exactly what is included in the resource? The only definition of geothermal resources in Montana law is the following, from the state lạnds leasing statute:

"Geothermal resources" means the natural heat energy of the earth, including the energy, in whatever form, which may be found in any position and at any depth below the surface of the earth, either present in, resulting from, created by, or which may be extracted from, such natural 
heat, and all minerals in solution or other products obtained from the material medium of any geothermal resource.

Thus, on state-owned lands, geothermal resources include only the heat energy and by-product minerals, and not the steam or hot water itself. On federal lands, however, geothermal resources include "indigenous steam, hot water and hot brines".

On private lands, no definition clearly applies. In practice, though, the state's water laws apply to all geothermal developments involving production and diversion of geothermal fluids. Indeed, the definition of "water" in Montana's Water Use Act includes "geothermal water", though that term is not defined.

Thus, no matter who owns the geothermal resource, the developer must secure the necessary water rights. 


\section{LAND LEASING}

The following discussion of leasing presupposes that the issues of mineral definition and ownership discussed earlier have been resolved to the satisfaction of all parties.

\section{a. Federal Lands}

The Geothermal Steam Act of 1970 authorizes the Secretary of the Interior to issue leases for the development of geothermal resources on public, withdrawn and acquired lands administered by the Department of the Interior and by the U. S. Forest Service (Department of Agriculture). Lands not available for leasing under this Act include national recreation areas and 1 ands administered by the National Park Service, fish hatcheries, wildlife or game refuges, wildlife management areas, lands reserved for protection of threatened or endangered species, and tribally or individually owned Indian trust or restricted lands, either within or outside the boundaries of Indian reservations.

When an area is first considered for leasing, the Director of the Bureau of Land Management (BLM) will secure a description of the lands and the potential impact of geothermal development, and will determine whether leasing must be preceded by an environmental impact statement. An environmental impact statement is usually required when a number of applications have been submitted for lands in the same area, or when such a statement is required by the land management plan for the area. Decisions as to whether a lease should be issued, and whether to approve an environmental impact statement, are made by the agency with jurisdiction over the lands in question (i.e., the Forest Service or the Bureau of Land Management). 
The actual leasing of lands is the responsibility of the state BLM director. (If the land has been withdrawn for the benefit of another agency (e.g., Forest Service, Park Service or Fish and Wildlife Service), the head of that agency must consent to the lease.) Leases are sold either by competitive bidding or by non-competitive negotiation, depending on whether the proposed lease tract is within a "Known Geothermal Resource Area."

A Known Geothermal Resource Area (KGRA) is designated by the Secretary of Interior as aregion in which the geology, nearby discoveries, competitive bidding, or other indications would lead experts to believe the prospects for extracting geothermal resources are sufficient to warrant spending money for the purpose.

All of the lands covered by a geothermal lease application are designated KGRA if 50 percent or more of the lands are covered by another application in the same filing period. If less than half of the application is overlapping, that portion alone may be designated KGRA.

Lists of designated KGRA's are periodically published in the Federal Register. They are also available from the Deputy Conservation Manager - Geothermal, U. S. Geological Survey.

\section{Qualifications of Lessees}

Lessees must be citizens of the U.S., or associations of citizens, or corporations organized under federal, state or local laws. No one person or entity may own interests in federal geothermal leases of more than 20,480 acres in one state, except for geothermal leases that are part of an approved utilization or cooperative development plan. Stockholders or partners who 
control more than 10 percent of the stock or partnership will be charged with their pro rata share of the leasehold interests of any corporation or partnership.

\section{Non-Competitive Leasing}

Federal lands which have not been declared a KGRA or reserved from mineral leasing by the Secretary of the Interior are available to the public for geothermal leasing without competitive bidding. The appropriate application forms and guidelines for submission are available from the state BLM director's office in Billings. The application should include a proposed plan for diligent exploration, including maps of the lease tract, a narrative description of plans for pollution control, fire and erosion prevention, wildlife protection, and so on, and a statement that the applicant does not hold over 20,480 acres of federal geothermal leases in the same state.

An application must be submitted in a sealed envelope marked "Application for a Lease Pursuant to 43 CFR subpart $3210^{\prime \prime}$ and be accompanied by a payment of fifty dollars $(\$ 50.00)$, a service charge.

Each calendar month is a separate filing period. If leases are applied for by more than one applicant for the same tract during the same month, that tract will be designated KGRA, and must be opened to competitive bidding.

\section{Competitive Leasing}

To qualify for competitive bidding for a KGRA lease, an application (nomination) must be filed with the proper BLM office stating:

(1) The person's (company's) name and address.

(2) Statement of citizenship and qualifications for leasing.

(3) Site description. 
(4) Declaration of interests in any other Federal geothermal leases within the same state.

The notice of competitive bid for the KGRA lease will be published once a week for four (4) consecutive weeks in the area where the lands are located. The notice will include all pertinent information including terms and conditions of the sale, royalty and rental terms. Each bidder must submit a sealed bid with a certified or cashier's check for one fifth the amount bid. The lease will be awarded to the largest cash bonus bid, though the Federal government reserves the right to reject any and all bids. All monies submitted with rejected bids will be returned to the applicants.

The successful bidder must pay the balance of the bid amount in no more than two annual installments.

\section{Lease Terms}

Leases are issued for a primary term of ten years. A lease may be extended five years, if diligent drilling is going on, and so long thereafter as commercial production occurs, up to 40 years after the end of the primary term. The lessee has a preferential right to a second 40 -year term.

Lease tracts must be at least 640 acres, except for non-electric uses, but are generally 1 imited to 2560 acres. A lessee may hold more than one lease, subject to the statewide acreage limitation described above.

Rent must be at least $\$ 1 / a c r e$, increasing by $\$ 1 /$ acre each year after the fifth year until commercial production begins. Exploration expenditures during the first five years, and expenditures in excess of the minimum required for subsequent years, may be credited to the escalated portion of the rent. Rents are paid each year in advance, to the BLM state director. 
Royalties must be at least 10 percent and no more than 15 percent of the value of steam or other heat or energy sold or used by the lessee, and no more than 5 percent of the value of by-products (including demineralized water) sold, used or reasonably susceptible to use by the lessee. Water used for generating electricity is not subject to royalty, and any by-product which is a locatable mineral (e.g., gold, silver, copper or other hardrock mineral) under the 1920 Mineral Leasing Act will be subject to royalties as set in that act. Commencing in the month after commercial production begins, a $\$ 2 / a c r e$ minimum royalty will be paid in lieu of rent. Royalties are paid monthly to the geothermal office of the USGS.

Rental and royalty terms may be adjusted every 20 years, beginning 35 years after production of geothermal steam. The maximum increase for any single adjustment is 50 percent, with an over-all maximum royalty of $22 \frac{1}{2}$ percent. Other lease terms may be adjusted at 10 year intervals, beginning 10 years after production of geothermal steam.

Before exploration of leased lands begins, the lessee must file a lease compliance bond of $\$ 10,000$ and a surface bond of $\$ 5,000$. A statewide bond of $\$ 50,000$ (to cover all operations in the state) or a nationwide bond of $\$ 150,000$ may be filed in lieu of bonds for a single lease. Bonds are filed with the state BLM director.

\section{b. Indian Lands}

Leasing regulations for Indian lands apply generally to all minerals. No regulations apply specifically to geothermal resource development.

An individual may grant a mineral lease on his or her own lands, but the lease must be reviewed and approved by the Bureau of Indian Affairs. Required 
lease terms and conditions are set forth in the regulations. For leases on allotted lands, applications should be submitted directly to the local BIA agency .

For tribally-owned lands, leases may be issued by the tribe, with BIA approval. Leases are sold by competitive bidding, unless the BIA gives permission for a negotiated lease, but the Secretary of the Interior reserves the right to reject a negotiated lease and call for bids.

After the tribe approves, the superintendent of the appropriate Indian agency will publish notice of a lease sale. Bids must be accompanied by 25 percent of the bonus bid. The successful bidder must pay the balance plus the first year's rent within 30 days after the lease is awarded. The Secretary of the Interior may reject all bids, re-open the sale, or approve negotiations with individual applicants.

The applicant must furnish a compliance bond, the size of which depends on the acreage leased. Leases must be in compact tracts of no more than 2560 acres per lease. The lease term is for 10 years and for so long thereafter as commercial production occurs. A minimum rental of $\$ 1 /$ acre must be charged, and royalties must be at least 10 percent of the value of 'minerals' marketed. At least $\$ 10 / a c r e / y e a r$ must be spent for development activities. Operations may not begin without written approval from the U.S. Geological Survey and the Secretary of the Interior.

These regulations may be superceded by tribal ordinances. The developer should contact the appropriate Tribal Council or BIA Indian agency to find out whether a tribal mineral leasing code has been adopted.

\section{c. State Lands}

The State Board of Land Commissioners (Board) is authorized to grant leases on state-owned land "for prospecting, exploration, well construction, and the 
production of geothermal resources." The Board has jurisdiction over school trust lands, beds of navigable waters, and other acquired lands, but not over recreational lands or lands owned and used by state institutions for public building sites, campus grounds, or experimental purposes. Regulations adopted to implement the law are administered by the Department of state Lands (Department), and the Director of the Department (The Commissioner of State Lands) reports to the Board.

\section{Application Procedures}

The Board may exercise "business discretion" in entering into lease agreements, but initial discretion lies with the Commissioner. A person wishing to obtain a lease for geothermal exploration or development on lands administered by the Board must file an application with the Department describing the tract and the proposed activities. A nonrefundable $\$ 10$ fee must accompany the application for each tract. Even "casual exploration" is prohibited until a lease is applied for and approved.

The Commissioner will announce a public lease sale when sufficient applications are received for a given tract, or "at the Commissioner's discretion." Sealed bids are then invited. Bids must be accompanied by one-fifth of the amount bid, to be returned if the bid is unsuccessful. If only one person bids for the tract, the applicant may negotiate a lease with the Department, but the Board may choose to reject all bids and applications. If a lease is granted, the lessee must pay a $\$ 25$ fee plus the remaining four-fifths of the first year's rental.

\section{Lease Terms}

The primary term of a lease is ten years "and for so long thereafter as geothermal resources in paying quantities are produced." If, at the end of 
the primary term, production has not begun but the lessee is actively engaged in drilling, the lease will be extended while drilling continues and thereafter as long as resources are produced.

Leases are limited to 640 acres per lease, but there is no limit to the number of leases a person may hold. Leased lands are to be in contiguous and compact tracts so far as possible.

The lease must provide for a royalty of at least 10 percent of the gross revenue from the sale of heat energy, steam, brines, and associated gases. (If the lessee also owns and operates an energy-generating facility using the geothermal energy produced from the leased property, the royalty is based on the fair market value of such heat energy or steam.) The lease must also set a royalty of no less than two percent and no more than five percent of gross revenue from the sale of mineral by-products recovered from geothermal fluids, and no more than ten percent of the revenue from operation of a geothermal spring for health or recreation purposes. A rental of at least one dollar per acre per year is also assessed.

Once geothermal resources are discovered in commercial quantities, total yearly payments must be at least two dollars per acre. If "diligent exploration" has not commenced or is not continuing by the end of the third year of the lease term, a delayed exploration penalty of at least two dollars per acre is assessed at the end of each year until exploration begins.

Lease terms allow for pooling and unit operation agreements with other operators, but such agreements must be approved by the Board. Leases also recognize the rights of prior surface lessees. The geothermal lessee is entitled to such access as is necessary to develop the resource, but the surface lessee must be compensated for any damage caused by the geothermal activities. Furthermore, the state reserves the right to sell or lease non-conflicting 
surface interests notwithstanding the existence of a geothermal lease. In case of conflicts between lessees, the earliest lease has priority of rights.

If development of the geothermal resource requires the acquisition of water rights, the lessee may apply to the Board for permission to secure such rights, and if permission is granted, the lessee may file an application in the name of the State of Montana in accordance with the Water Use Act.

Improvements which are not removed within 60 days after expiration of a lease become state property, but a subsequent lessee must reimburse the earlier lessee for the value of such improvements.

\section{Other State Agencies}

If geothermal resources are located on state-owned lands other than those under Board jurisdiction (e.g., state institutions, recreational lands), the regulations described above do not apply and lease negotiations must be conducted with the agency involved, assuming that the agency's own statutes do not prevent it from leasing its property for geothermal development. Lease negotiations would be similar to those involved in private leasing (see below), though it is likely that the agency would apply reclamation, performance, bonding and other requirements comparable to those described above.

\section{d. Local Government Land}

Leasing lands owned by a municipal or county government requires negotiation with the city or town council or the county commissioners. A lease of municipal property must be approved by ordinance or resolution of the city or town council. County property that is not essential to county business may be leased by the county commissioners. In general, lease terms are subject to negotiation with the governing body. 
Counties are authorized to adopt regulations for the management, lease or sale of county-owned lands. The developer should check with the county commission to see if such regulations are in effect. Where such regulations apply, county lands may be leased for no less than the amount of taxes that would have been levied had they been private lands. The county may also assess such royalties as may be negotiated with the lessee. Lease terms for mineral development may be for up to ten years and as long thereafter as minerals are produced in commercial quantities. Leases may also be renewed by the county commissioners.

As with state leases, improvements become the property of the county if left on the land sixty days after expiration of the lease, but any subsequent lessee must reimburse the earlier lessee for the value of the improvements.

\section{e. Private Lands}

The negotiation of geothermal leases between private parties is not governed by the state law, other than the standard principles of contract law. Among the provisions that should be considered by the parties to a geothermal lease are:

- term (length) of the lease

- rent and royalty payments

- access to and use of the surface for resource development purposes

- "due diligence" provisions and penalties for delay in commencing exploration or operation

- water rights

- inspection rights

- surface disturbances, such as timber and crop removal; and reimbursement for such disturbances 
- reclamation requirements

- default provisions (e.g., failure to acquire state or federal leases on neighboring lands)

- "hold harmless" provisions for personal or property injury

- "force majeure" provisions (i.e., escape clause for circumstances beyond the control of the parties

- the right to enter unitization and pooling agreements with other operators

- provisions for assigning the lease to other parties

Advice of legal counsel is recommended, for the protection of all parties. 


\section{EXPLORATION AND DEVELOPMENT}

\section{a. Federal Lands}

Pre-Lease Exploration

"Casual use" of federal lands (i.e., activities that do not appreciably disturb the land and do not require heavy equipment, explosives, or off-road vehicles) may proceed without a permit after notice to the U.S. Geological Survey. ("Casual use" includes mapping, water sampling, aerial surveys, etc.) Before beginning more intensive exploration on BLM lands (e.g., drilling temperature holes, constructing roads), the developer must secure approval under a "Notice of Intent and Permit to Conduct Exploration Operations." This application is submitted to the BLM office in Billings, with a $\$ 5,000$ bond. It must include a brief description of the type of operation, the lands to be explored and the approximate dates of activities. The BLM district manager must make his decision within 30 days.

Pre-lease exploration on U.S. Forest Service Lands requires a "Prospecting Permit," for which application must be made to the local Forest Supervisor. Geophysical and geochemical surveying and shallow test drilling is allowed under this permit, but core drilling and development wells require a lease. Casual use and exploration under a Notice of Intent are not exclusive rights, and do not confer any preferential rights to a lease.

\section{Operations (Under Lease)}

After a lease is awarded, an operator may not begin development until a "plan of operations" is approved by the USGS Deputy Conservation Manager Geothermal (DCM-Geothermal) and by the agency with jurisdiction over the lease lands. This plan must contain the location of each well, provision for access 
and water supply, description of other surface disturbances, waste disposal plans, environmental protection measures, and monitoring provision. Baseline data must be collected for one year prior to geothermal production.

Where operations are to be conducted by someone other than the lessee, a "designation of operator" form must be submitted.

Deep exploration drilling, development, production and utilization are considered major surface-disturbing activities and therefore require an Environmental Assessment prepared or coordinated by the DCM-Geothermal. The Environmental Assessment will discuss the effect of the proposed operation on the environment, recommend mitigating measures to be taken, and determine whether the operation will be a "major Federal action significantly affecting the human environment," in which case an Environmental Impact Statement will be required. Public and agency comment will be taken into account during this assessment period.

If an Environmental Impact Statement is not required, the plan of operation may be jointly approved by the DCM-Geothermal and the relevant agency, incorporating the mitigating measures of the Environmental Assessment as conditions of approval. An approved plan of operation does not authorize deep drilling or construction, for which the lessee must obtain permits from the DCM-Geothermal. Drilling operations and methods must be approved before drilling is begun, and precautions must be taken to avoid waste and ground-water contamination. The operator must comply with all state and federal pollution control and noise abatement standards, and must minimize or mitigate subsidence and seismic impacts. Well plugging and abandonment must conform to required standards and procedures. 
Advance notice must be given for casing tests, repair or recondition of a well or casing, well stimulation, or well abandonment, and a report must be filed within 30 days afterward. Complete well logs must be submitted to the USGS within thirty days after each well is completed. The lessee must also submit monthly reports of operations, sales and royalties, and annual reports describing exploration expenditures and compliance with environmental protection requirements.

All pre-lease and post-lease activities except casual use require a cultural and biological clearance from the relevant agency (BLM or Forest Service). The lessee will usually be required to conduct an archeological and Native American religious site survey, and sometimes a biological survey for threatened or endangered species as well.

The lessee is required to conduct "diligent exploration" until geothermal resources are produced in commercial quantities. After the fifth year of the lease term, exploration expenditures must equal or exceed twice the sum of the minimum annual rental required by law plus the excess of the current year's rent over the fifth year's rent, but in no case will expenditures in excess of twice the 10th year's rent be required. Expenditures in excess of these amounts may be credited forward to subsequent years.

The DCM-Geothermal may require production of valuable by-product minerals unless such production does not conserve resources or is not economically feasible. The lessee must periodically report the by-product content of geothermal fluid.

The lessee will also be required to drill off-set wells to prevent geothermal fluids from draining into adjacent non-federal land.

All unitization and pooling agreements for cooperative development of tracts must be approved by the USGS. Such an agreement may be required when it is necessary for optimum resource recovery or to prevent waste. 
All sales contracts entered by the lessee for sale of geothermal steam, heat or other energy must be filed with the USGS within 30 days.

b. State Lands

Exploration may not commence on state lands (i.e., lands under the jurisdiction of the Board of Land Commissioners) until a lease has been obtained. Before disturbing the land (e.g., by using earth-moving equipment or clearing timber) the lessee must notify the department of the name of the operator, the location of operations, starting and (estimated) completion dates, size and scope of the operation, and the general methods of operation (see below). The lessee is entitled to occupy and use only so much of the land as is necessary for exploration, drilling, production, and marketing the resource, and may not unreasonably interfere with prior surface uses (such as grazing).

The lessee is required to conduct "diligent exploration", including geochemical surveys, heat flow measurements, core drilling and test wells, until geothermal resources are being produced in commercial quantities. Annual reports must be submitted to the department detailing all exploration activities and expenditures. After the third year of the lease term, exploration expenses must equal at least four times the yearly rental. If diligent exploration is not occurring, a delayed exploration penalty will be assessed. The lease may be cancelled for failure either to "diligently" explore or to pay the penalty.

\section{Operations}

The lessee is required to use "best practices and engineering principles" in his operations, and the regulations set minimum requirements for well casings, plugging and abandonment procedures, and waste disposal. Surface lands disturbed by exploration, development, operation and utilization activities must be reclaimed by restoring original contours, stockpiling topsoil, reseeding, 
and revegetation. The Department of State Lands may inspect the operation at any time to ensure compliance with these requirements.

Before any deep well (1000 feet or more) is drilled, a $\$ 10,000$ bond must be filed, and a "plan of operations" must be approved by the department. This plan must set forth the location of each well, means of access, source of water supply, waste disposal plans, measures for environmental protection and pollution controls and other information required by the department.

Production and sales reports must also be submitted regularly to the department.

All exploration, production and injection wells must be cased, plugged and abandoned according to the technical requirements set forth in the regulations. Notice of intent to abandon a well must be filed with the department at least five days in advance, and a report on abandonment work must be filed within thirty days after the work is completed.

Within sixty days after a well is plugged and abandoned, the lessee must file a drilling and production history. This information may be used by the Department of State Lands or other state agencies for planning further geothermal resource development, but it is confidential and will not be made public for two years.

\section{c. Seismic Exploration}

Anyone who plans to conduct geophysical seismic exploration using explosives must first file a notice of intent with the appropriate county clerk and recorder, and file a surety bond with the Secretary of State to indemnify property owners $(\$ 10,000$ for one crew, $\$ 25,000$ for two or more crews.) The bond will be held for at least five years after exploration is completed. After the Secretary 
of State certifies the bond, the county clerk and recorder will issue a permit good for one calendar year (fee, $\$ 5,000)$.

The county clerk will notify the State 0 il and Gas Conservation Board that the permit has been issued. The $0 i 1$ and Gas Board will check a state-wide list of seismic exploration operations (maintained by the Department of Natural Resources) and will notify the county if the applicant is currently in violation of any drilling regulations.

Surface owners must be notified of the schedule of operations in advance, and written permission from the surface owner is required for shots within a quarter of a mile of any building, structure, water well or spring, or within an eighth of a mile of any reservoir dam. A report must be filed with the county clerk and recorder within three months after each firing.

Shot holes must be plugged and the surface area restored to its original condition in compliance with regulations enforced by the Board of $0 \mathrm{il}$ and Gas Conservation. The Board must be notified of the intent to plug and abandon a hole, and plugging must be accomplished within 120 days after drilling and firing (unless the surface owner requests that it remain open as a water well.)

\section{d. Well Drilling}

Water well drilling on Federal, state or private land is regulated by the Board of Water Well Contractors, with the purpose of minimizing waste and avoiding contamination of ground water. The law applies to persons drilling to locate or acquire ground water, but not to persons prospecting for or obtaining "minerals or products of mining." Whether this law applies to geothermal exploration is not clear, and will have to be determined by a declaratory ruling of the Board, by an attorney general's opinion, or by litigation. The 
geothermal developer should be aware of these provisions, however, and be prepared to comply with them.

If the law does apply, it means that well drilling must be carried out under the personal supervision of a licensed water well contractor. To obtain a license, the applicant must have completed one year of apprenticeship under the supervision of a licensed contractor, and must pass a written or oral examination designed to test his or her knowledge of drilling techniques, well construction, geology, ground water laws, etc. The fee is $\$ 100$. This license may be renewed annually, with a $\$ 25$ renewal fee.

The Board's rules set standards for materials, techniques, sealing, casing, and plugging. Water well contractors must file a surety bond of $\$ 1000$ conditioned on compliance with these rules, before beginning operations in Montana. They must also maintain complete well logs to be made available to the well owner and to any state agencies requiring such reports.

\section{e. Water Use Permit}

Geothermal wells or hot spring diversions on federal, state or private land are subject to the requirements of the Montana Water Use Act.

A provisional permit must be obtained from the Department of Natural Resources and Conservation (DNRC) before 1) any surface water is diverted from a stream or lake, 2) any groundwater is appropriated from a well capable of producing 100 gallons per/minute or more, or 3) any groundwater is appropriated inside a designated "controlled groundwater area". An interim permit should first be obtained for preliminary exploration and test drilling for groundwater.

At the exploration stage, it may be impossible to estimate the volume of flow from an exploration hole. But if the intent is to develop the hole for production purposes, should adequate flow be encountered, then DNRC will require 
an interim water use permit for drilling and testing. Hole size, water use, capping of wells, and other conditions will be imposed on interim permit holders.

Pêrmit application forms are available from the DNRC or from the county clerk and recorder. Welis producing less than 100 gallons per minute do not require a permit, but a Notice of Completion of Groundwater Development must be filed with the department within 60 days after the well is completed.

The department has 30 days after receipt of a permit application to determine whether the application is complete. If it is not, the applicant may be allowed up to 18 months to supply the necessary information without loss of priority:

Fees for water appropriation applications are based on the volume of water applied for. They range from $\$ 5$ for less than eight acre-feet per year up to $\$ 550$ for 50,000 acre-feet per year, plus $\$ 5$ for each thousand acre-feet per year over 50,000 .

DNRC review of applications for 15 cubic feet of water per second or more, or 10,000 acre-feet per year or more, may require preparation of an environmental impact statement. If so, a fee may be assessed according to the estimated cost of the project. DNRC and the applicant may negotiate the amount of the fee and the use of environmental information produced by the applicant or a third party.

When DNRC receives a complete application for a water use permit, it must pubilish the information in a local newspaper for three weeks and also serve notice on pritor users who may be affected. (Notification procedures may be omitted if DNRC determines that issuing the permit witl not interfere with existing rights. ) 
Any objection to the application must be filed with DNRC between 30 and 60 days after the last public notice. If DNRC determines that the objection is valid, it must hold a public hearing within 60 days after the end of the comment period.

A permit application usually must be granted or denied within 120 days after publication (or 180 days if a hearing is held). Time extensions up to 60 days are available under certain circumstances. If DNRC denies the application or proposes modifications, the applicant has the right to a hearing.

The Department must issue a permit when the following criteria are met:

a. unappropriated waters in the supply source are available, in the amounts and at the times of year required by the applicant;

b. the rights of prior appropriators will not be affected adversely;

c. the proposed means of diversion or construction are adequate;

d. the proposed use of the water is a "beneficial use";

e. the proposed use will not interefere unreasonably with other planned uses or developments for which a permit has been issued or for which water has been reserved;

Legislative approval is required for any appropriation of ground water that exceeds 3000 acre-feet per year, unless the appropriation is for a public water supply or for irrigation of the applicant's cropland.

DNRC may attach conditions to the permit regarding construction, or it may issue a permit subject to conditions and restrictions intended to protect the rights of other appropriators. Permits may be temporary or seasonal.

An approved permit must be recorded with the county clerk and recorder in the county where the point of diversion or the place of use is located, and 
a duplicate must be filed at DNRC in Helena. The permit may be revoked if its conditions are violated. A certificate of water right will be issued when the applicant actually begins using the water after existing rights in the area have been adjudicated. Until then, the certificate is provisional and might be changed if it is determined later that the applicant's use interferes with existing rights.

Once granted, water rights may be transferred only with DNRC approval. DNRC approval is also required for any change in the use of previously appropriated water. Such approval must be given if the change will not affect the rights of other water users. If other users may be adversely affected, DNRC must provide for notice, objections and a hearing as described above.

\section{Ground Water Regulations}

In addition to issuing water appropriation permits, DNRC is responsible for preventing waste or contamination of ground water. It may inspect water wells to assure that proper casings, fittings, valves and other equipment and methods are being used. Within 60 days after a well is completed, the driller must file a well log report with DNRC and with the county clerk and recorder. DNRC will send a copy of this report to the Montana Bureau of Mines and Geology.

On its own motion, or on petition of the ground water users in an area, DNRC may, after public notice and hearing, designate a controlled ground water area for the purpose of preventing excessive ground water withdrawals. Special restrictions may be imposed on ground water use in such an area.

\section{f. Public Water Supplies}

Anyone drilling a water well to furnish water for public consumption must file well logs with the Water Quality Bureau of the Department of Health and 
Environmental Sciences. If it is anticipated that spent geothermal water will be potable and may be used for a public water supply, the Water Quality Bureau should be notified before drilling begins. 


\section{LAND USE REGULATIIONS}

In addition to laws and regulations governing natural resource development and energy production, there are a number of land-use regulations applicable to all phases of resource exploitation, from exploration to marketing. The nature of geothermal resources is such that the end-use facility (e.g., space heating or electric generation) must be located fairly close to the resource development site. Bevelopers should therefore ascertain whether any land-use reguliations apply before making any serious commitment to exploration.

\section{a. Zoning.}

Within cities and towns, city councils may adopt master plans and establish zoning ordinances that restrict land use activities. Outside cities and towns, county governments are similarly authorized to adopt master plans and zoning regulations, though Montana law prohibits county zoning regulations that would prevent the use and development of mineral resources. Few counties in Montana have adopted county zoning ordinances.

Special zoning districts may be established in unincorporated areas on petition of 60 percent of the residents of such an area. Within such a specially created district, land use plans and zoning ordinances may be established and enforced by the county.

Potential developers may have to apply for a permit from the city council or the county commission to engage in exploration or development activities. If the proposed activities are inconsistent with zoning ordinances, the applicant is entitled to seek a variance from the Board of Adjustments.

Zoning ordinances do not exist everywhere - they are uncommon in rural areas - and the regulations vary from place to place. Geothermal developers 
should contact the appropriate city or county agency to see whether such ordinances are in effect, and what permit requirements are applicable.

b. Floodways and Floodplains

Special land use restrictions may apply within the floodways and floodplains designated by DNRC. The purpose of such regulations is to restrict land uses which may be dangerous during floods or may increase the severity of flooding. Most land uses will require a permit either from the local government agency (city council or county commission), or from DNRC, if the local authorities have not yet adopted permit procedures. Permit applications should be accompanied by a $\$ 10$ filing fee. The permitting agency must make its decision within 60 days, except in cases where the application is made to DNRC and it is determined that an environmental impact statement will be required. The developer may apply for a variance from the regulations, but variances issued by the local authorities must be approved by DNRC.

\section{c. Lakeshores}

Special land use restrictions may apply to activities within twenty feet of the high water mark of a natural lake, so as to preserve the scenic value of such areas. The local agency (city council or county commission) is required to adopt and enforce permit procedures. If they fail to do so, landowners occupying a lakeshore may petition DNRC to adopt and enforce rules.

Anyone who proposes a project that will alter or diminish the course, current or cross-sectional area of a lake or its shore must secure a permit from the appropriate agency. (Examples include channels, ditches, dredging, filling, construction of piers, etc.) A fee of $\$ 10$ should accompany the 
application. The permitting agency will consult with the local planning board (if one exists) and must reach a decision within 90 days. The applicant may seek a variance from the applicable regulations, but the permitting agency must prepare an environmental impact statement (at the applicant's expense) and hold a public hearing before granting such a variance.

\section{d. Streams and Streambanks}

Any activity with a physical impact on a stream or its banks is subject to review by local, state and federal agencies. Examples include construction of pipelines, powerlines, or roads across streams, dredging or filling, stream channelization or diversion, etc.

\section{Local and State Review}

Montana's Streambed Preservation Act is designed to minimize erosion and to protect the "beneficial uses" of the state's waters. Anyone planning a project that will physically alter or modify a perennial stream or its banks must send written notice (including the location and a description of the project) to the supervisors of the local soil and water conservation district or grass conservation district, or to the county commission if no conservation district has jurisdiction. The local supervisors must determine whether the proposed activity is a "project" as defined by the law. If so, the applicant and the Montana Department of Fish, Wildlife and Parks are notified within five days.

- The Department has five days to request an on-site inspection, after which the local supervisors have 20 days to convene an inspection team consisting of representatives of the supervisors, the Department, and the applicant. The team members submit written reports within 50 days of the application, recommend- 
ing approval, denial, or modification of the proposal. The supervisors review these reports and make their decision within 60 days of receipt of the application. The supervisors' decision is based on the purpose of the project, sediment effects, interference with property, and available mitigative measures. Efforts must be made to minimize the impact on stream flow, fish habitat, etc.

\section{Federal Review}

A permit from the Army Corps of Engineers is required for any activity involving dredging or filling of "waters of the United States". By definition, the "waters of the U.S." includes all tributaries of navigable streams.

Permit application is made to the district engineer of the Corps of Engineers. The application must include a complete description of the proposed activity: plans, site location, purpose, use, approvals required by other government agencies, and type of discharge, if any. A fee of up to $\$ 100$ may be assessed. If an environmental impact statement is required, the applicant may be assesised the costs of its preparation.

If state approval is required, the district engineer will not approve the application unless the state does. If the state grants approval or if the state takes no action within six months, the district engineer may continue processing the application.

After reviewing the application for completeness, the district engineer issues a public notice and allows up to 75 days for comments. If comments or objections warrant it, a public hearing will be held. The district engineer must decide within 30 days after receiving notice of withdrawal of objections, or after receiving the record of the public hearing, or after the waiting period after filing a final environmental impact statement expires, whichever event occurs last. 
Approval generally will be granted if the project complies with the goals and standards of the National Environmental Policy Act, the Fish and Wildife Coordination Act, the Historic and Archeological Preservation Act, the National Historic Preservation Act, the Endangered Species Act, and the Federal Water Pollution Control Act. The district engineer must consider the comments of the regional director of the Bureau of Sport Fisheries and Wildlife, the regional administrator of the Environmental Protection Agency, the local representative of the Soil Conservation Service, and the heads of appropriate state agencies.

\section{e. Erosion Control}

Conservation district supervisors may, after approval by the voters in the district, adopt land-use regulations in the interest of conserving soil and water resources and preventing and controlling erosion. If adopted, the regulations have the force of law.

The regulations must provide for a board of adjustments which may grant variances from the regulations because of practical difficulties and unnecessary hardships which would be entailed in complying with the regulations.

The Lewis and Clark County Conservation District is the only district in Montana that has adopted such regulations. They require most subdivision, forestry, and construction activities to be reviewed and approved by the district supervisors prior to any phsyical disturbance of land (e.g., clearing, grading, excavating, transporting, and filling of lands).

The developer must submit an erosion control plan to the district supervisors for approval before beginning any land disturbance. The supervisors will provide technical assistance in developing such a plan, which must include a topographical map, a soil information map, a construction time schedule, and an estimate of the exposure time of soil-disturbed areas. The supervisors have 
30 days to review the plans and either approve them or request changes. A plan is not required if the project is being carried out under the technical standards and specifications of the Soil Conservation Service of the U. S. Department of Agriculture.

The geothermal developer should contact the local soil and water conservation district to see if any such regulations are applicable.

\section{f. Open Space and Natural Areas}

Special restrictions may apply to lands that are valued for their open space or natural character. Local government agencies are authorized to acquire "conservation easements" or other interests in lands to restrict development activities in order to preserve open space values. State-owned lands may be designated "natural areas" and placed under management plans to preserve the unique character of such areas. Developers should contact local officials and the Department of State Lands to determine whether the proposed geothermal activity will affect any such areas.

\section{g. Forests}

If proposed activities in forested areas will involve tree cutting (e.g., to clear right-of-way for pipelines, transmission lines, etc.) the operator is required to take measures to minimize fire hazards. DNRC must be notified at least ten days before clearing begins. The developer must reach an agreement with the department regarding the manner of slash disposal and other fire hazard reduction. Open burning of slash or other waste material requires a permit from the local fire control officer. 


\section{FACILITY SITING}

\section{a. The Major Facility Siting Act}

The Montana Majọr Facility Siting Act provides for the comprehensive review of the siting and construction of facilities that generate, convert, and distribute energy. The law is administered by the Facility Siting Division of DNRC. it applies to

- facilities designed for or capable of generating fifty megawatts of electricity or more;

- pipelines designed for transporting water from or to such a facility;

- electric transmission lines of a design capacity of more than $69 \mathrm{kv}$ and more than $10 \mathrm{miles}$ long, or more than $230 \mathrm{kv}$ and 10 miles or less in length.

- any use of geothermal resources for the creation, use or conversion of energy, designed for or capable of producing 25 million Btu-equivalent or more of geothermally derived power.

No one may begin to construct such a facility without first obtaining a certificate of environmental compatibility and public need from the Board of Natural Resources and Conservation. Preliminary exploration, and securing geological data by test hole drilling do not require a certificate under the Siting Act, though reports of geothermal exploration must be submitted to the DNRC. A siting certificate is required for eminent domain proceedings, or for fracturing underground formations in preparation for geothermal development. 
If there is no possibility that the geothermal development will be capable of producing 25 million Btu per hour, then the siting Act does not apply. The reports described below should be filed, however, if there is any possibility that the developed resource will yield power at or above the 25 million Btu level.

\section{Long-Range Plans}

Exploration activity related to the "possible future development of a geothermal facility"must be reported to DNRC, though a certificate under the Siting Act is not required. Anyone who expects to undertake geological exploration related to potential future development of geothermal resources during the next ten years must file a long-range plan with DNRC describing the location, nature, and approximate dates of exploration activities. Starting sixty days before test-hole drilling or other underground activities begin, and at sixty-day intervals thereafter, field reports are to be filed with the DNRC describing the area of exploration; number, location, and depth of holes; methods of drilling, casing, and closing; sampling reports; summaries of environmental impacts and mitigating measures, etc. Within nine months after exploration begins, and at six month intervals thereafter during the investigation, geological reports are to be filed, including well logs, geological measurements, rock structures, temperatures, rock and soil composition, etc. These data are for the use of state agencies and will remain confidential for two years following commencement of test-well drilling, or for six months following completion of a commercially productive well.

Anyone who plans to construct a regulated facility during the next ten years must file an annual long-range plan with DNRC by April 1st each year. The long-range plan must describe the general location, size and type of 
of facility, projections of demand for the services to be provided, efforts to cooperate with environmental protection and land-use planning agencies, and approximate date for filing the formal certificate applications. In addition to DNRC, long range plans are to be filed with the Envi ronmental Quality Council, the Departments of Health and Environmental Sciences, Highways, Public Service Regulation, State Lands, Fish, Wildlife and Park's, and Community Affairs, and any local governing bodies in the areas affected by the facility.

The DNRC may begin to evaluate a facility identified in a long-range plan for construction within the next five years.

No certificate application will be accepted for a facility not identified in at least two annual long-range plans.

Notice of Intent

A potential applicant may file a notice of intent to file an appi ication before filing a formal application. The notice must contain much of the information required in the application. If an adequate notice of intent is filed twelve months before the formal application, the applicant is entitled to a 5 percent reduction in the filing fee.

\section{Application}

A joint application is filed with the DNRC and the Air and Water Quality Bureaus of the Department of Health and Environmental Sciences (DHES).

The application must include a description of the facility, its location, and environmental studies performed by the applicant. It must also explain the need for the facility and describe alternate sites, and provide baseline environmental data for the primary and alternate sites. Copies of the application must also be sent to the agencies that recelive the long-range plan (listed above), and to the Department of Revenue. Public notice must be arranged by 
the applicant in the primary and alternate site areas. The applicant must pay a filing fee based on the estimated size and cost of the facility.

When the application is complete, DNRC and DHES conduct intensive technical and environmental analyses of the proposed facility. Within one year after accepting a completed application, DHES must determine whether the project complies with air and water quality standards. A copy of the DHES decision is sent to the Board and Department of Natural Resources.

Within 22 months after accepting the completed application, DNRC must complete its study, prepare its environmental impact statement, and report its recommendations to the Board. The Board must hold a public hearing within 120 days after receipt of the Department's report.

At the hearing, the applicant must show, by clear and convincing evidence, that the application should be granted and that the environmental criteria set out in the act will be met. The hearing officer must submit proposed findings of fact and conclusions of law to the Board within 60 days, and the Board must issue a written opinion within 60 days after receiving the hearing officer's report. The certificate may not be granted unless the Board finds that

a. the facility represents the minimum adverse environmental impact with respect to land use patterns, water resources and water quality, air quality, solid waste disposal problems, radiation, and noise;

b. the facility is consistent with regional plans for expanding utility grids;

c. the facility complies with applicable state and local laws and regulations; 
d. the Department of Health and Environmental Sciences and the Board of Health have certified that the facility will not violate state and federal air and water quality standards and implementation plans;

e. the facility serves the public interest, convenience, and necessity and satisfies an identified need (this finding refers only to public utilities). In making this determination, the Board must consider the need, environmental impact, benefits to the applicant and to the state, the resulting economic activity, and the effects on public health, safety, and welfare.

The certificate, if granted, must include an environmental evaluation statement discussing unavoidable adverse impacts, objections raised by other agencies, alternatives to the facility, a monitoring plan, and a statement of agreement by the applicant to abide by any conditions imposed. The Board may waive provisions, however, if an emergency showing is made. Any party may appeal the Board's decision to district court.

\section{Unified Procedures}

Notwithstanding other laws, no other state or local agency may require any permits or other authorizations for construction or operation of a facility if certification has been granted under this Act, but air and water quality agencies retain their authority to enforce state and federal standards and implementation plans.

\section{b. Electric Generation on Federal Lands}

A license is required for using federal geothermal-leased lands to produce electric power. License application is made to the BLM office in Billings, 
accompanied by a $\$ 50 \mathrm{filing}$ fee. The application must include a description of the land and of the facility to be constructed, connections with existing utility lines, sales or other utilization plans, and a copy of any agreements with the geothermal lessee, if different from the license applicant. The BLM will conduct an environmental and technical analysis of the application and determine whether an environmental impact statement will be required. Approval will also be required from the U.S.G.S. Deputy Conservation Manager - Geothermal and from any other land management agencies with jurisdiction.

The 1 icense term is 30 years, with a preferential right to renewal. Rental must be at least $\$ 100 / a c r e$, paid annually in advance, and a surety bond of at least $\$ 100,000$ must be furnished.

These regulations do not apply to research and demonstration facilities of 20 megawatts or less, if they are designed for not more than five years of operation, nor do they apply to non-electric uses of geothermal energy. 


\section{ENVIRONMENTAL PROTECTION}

\section{a. Air Pollution Discharge Permit}

New air pollution sources with the potential to emit 25 tons per year (tpy) of any regulated pollutant must be reviewed by the DHES Air Quality Bureau before construction. A permit is also required for a drilling rig using an engine of more than 2000 horsepower if fueled by natural gas, or more than 1000 horsepower if liquid fuel is used.

For the standard pre-construction review, a permit application should be filed at least 180 days before construction begins, or, if no construction is required, 120 days before equipment is installed. The department has 30 days to review the application for completeness and request additional information. The applicant is responsible for publishing notice of the application in local papers. Within 40 days after receiving a complete application, DHES must make a preliminary finding as to the project's conformity to air quality standards, and a final determination must be made within 60 days after receipt of a complete application. If an environmental impact statement is required, this period is extended to no more than 180 days to allow for the necessary reviews. If the applicant is seeking certification under the Facility Siting Act, the time schedule mandated by that Act will apply.

The regulations set forth emission limits, performance standards, ambient air quality standards, monitoring requirements, etc. A permit will be granted only if these standards can be met. Variances may be applied for, however, and if granted, will require the applicant to follow a compliance schedule.

New sources will be required to utilize "best available control technology" $(B A C T)$. BACT is determined on a case-by-case basis, with reference to economic feasibility and the state of the art for the particular technology. 
Additional Review of Major Sources

Pollution sources with the potential to emit 250 tpy of any regulated pollutant are considered major sources and will be subject to certain federal regulations.

If the facility will affect regions whose ambient air quality is currently better than national standards, "prevention of significant deterioration" (PSD) procedures will apply. At present, the Environmental Protection Agency (EPA) is responsible for PSD review of major sources. At least one year of baseline monitoring data will be required before an application can be filed. An air quality impact analysis will be performed. Some of the pre-application monitoring and impact analyses may be waived if an initial screening indicates that the impact will not be significant. After making a preliminary determination, the EPA will ask for public comment. The EPA must take a final determination within one year after receiving a complete application.

Major sources in areas where ambient air quality standards are currently being violated are subject to additional "non-attainment" review by DHES. Such sources are subject to "lowest achievable emission rates" (i.e., the lowest emission rates currently being achieved by that technology anywhere in the country) for those pollutants for which ambient standards are violated. In addition, the operator must certify that all other sources owned and operated by that operator in the state conform to all applicable standards. Further, the applicant must provide for "off-sets", or sufficient reductions in existing emissions of the non-attainment pollutant in the area to achieve a net improvement in ambient concentrations of that pollutant, even after the new source is constructed. Such off-sets must produce a greater improvement than would ordinarily have been achieved under the State Implementation Plan. 
The federal PSD regulations are presently undergoing revision, and state regulations will be revised thereafter, so there is some uncertainty in the regulatory structure. The DHES Air Quality Bureau is the appropriate first contact to determine what procedures will be required for each case. For a major source, this contact should be made at least two years before the anticipated construction date to allow time for the year of pre-application monitoring, stould it be required. (For applications under the Siting Act, baseline studies will begin some four years prior to the construction date.)

\section{b. Water Pollutant Discharge Permit}

The Montana Pollutant Discharge Elimination System (MPDES) permit program applies to ali discharges of geothermal fluid into surface waters of the state. If geothermal fluids are held in artificial impoundments on privately owned lands, no permit will be required for discharge into such impoundments, but overflows from such impoundments into state waters will require a permit. Discharge into a sewage system which connects with a public treatment works does not require a permit. Discharge into a reinjection well is theoretically subject to MPDES permit procedures, but because Montana has not yet adopted water quality standards for ground water, the applicability of the program to injection wells is not clear. When the federal underground injection control program becomes operative, a state MPDES permit will not be required for injection wells.

\section{Discharge to Treatment Works}

If all wastewater is discharged into a municipal sewer system, no preconstruction review or discharge permit is required, but such discharges will be subject to pre-treatment standards to protect publicly-owned treatment works. 
Again, no pre-construction or pre-operation permit is required under pretreatment regulations, but a report must be submitted to the treatment works or to the state Water Quality Bureau within 90 days after discharges begin, and semi-annually thereafter. These reports will describe the nature and volume of discharges and the progress being made toward conformity to pretreatment standards.

If on-site pre-treatment storage ponds are required, care must be taken to prevent over-flow discharges from these ponds. If an over-flow is expected to affect surface waters, a discharge permit will be required from the state Water Quality Bureau (see below). At least six months lead time is required for processing this permit.

\section{Surface Discharge}

Without a current permit, it is unlawful to construct or operate a disposal system or any sewage or waste outlet which discharges into the waters of the state. Permit application must be made at least 180 days in advance of the proposed operation. The application must contain facility plans, soil conditions, operating procedures, and any other information that DHES deems necessary. Reports should include general site plans, general design conditions and process descriptions, waste flow diagrams for industrial waste.

After receiving the completed application, DHES makes a tentative determination based on effluent standards, performance standards, water quality standards, toxic and hazardous substance standards, and existing area-wide water treatment plans. If the application is tentatively approved, a draft permit is issued which contains effluent limits, compliance schedules, operating conditions, monitoring requirements, etc. If discharges will be 500,000 gallons per day or more (or in other appropriate circumstances), DHES will prepare a fact sheet as described in 37 FR \#247, Part 111, Appendix A. 
Public notice of the diraft permit is issued, and a 30-day comment perilod is provided. The final determination is made after the comment period and public hearing (if requested). Permit approval requires the concurrence of the EPA regional administrator in Denver. Permits are for tup to five years, and permit renewal follows similar procedures. The Bepartment's permit decision may be appealed to the Board of Health.

\section{c. Underground Injection Control}

The EPA is presently drafting fiinal regulations for the underground injection wells permitting program. Since Montana does not have an underground injection control program, all new geothermal reinjection wells will reguire a federal permit, issued by the EPA. (Injection well is in existence when the regulations are published may continue to operate up to five years before obtaining a permit.)

Permit applications must identify the well owner or operator, the location and purpose of the well, and include maps showing the geological and hydrological environment, available well data in the area, anticipated injection rates, source and character of the injection fluid, physical and chemical characteristics of the receiving geologic formation, injection procedures, contingency plans for accidental escape of fluid, etc.

Application may be made for an area permit, where several wells of the same type, under the same ownership, will be drilled into the same aquifer. After approval of an area permit, individual wells within that area may be approved summarily without the full public notice and hearing requirements.

After receiving a completed application, the EPA will make a tentative decision and, if the decision is positive, issue a draft permit, accompanied by 
a fact sheet or statement of the basis of decision. Public notice of the draft permit is followed by a 30-day comment period. A public hearing will be held if the comments reveal significant public interest. The final decision is made after the hearing.

The permit will contain extensive technical requirements relating to construction methods, mechanical integrity, casing, drilling logs and reporting, monitoring wells, operations, abandonment of wells, and fiscal responsibility of the operator. The fundamental rationale of the program is to prevent contamination of underground sources of drinking water from injection wells, and requirements for emergency contingency plans and corrective actions will also be included in permits.

If a project requires permits under more than one EPA-administered program, or both federal and state programs, provision may be made for consolidating review procedures and time schedules.

\section{d. Environmental Impact Statements}

The Montana and National Environmental Policy Acts are virtually identical in their statements of policy and directions to administrative agencies. The laws declare a state (national) policy of encouraging "productive and enjoyable harmony between man and his environment" and direct state (federal) agencies "to use all practicable means, consistent with other essential considerations of state (national) policy, to improve and coordinate state (federal) plans, functions, programs, and resources" to achieve the environmental goals of the acts.

Both laws require preparation of an environmental impact statement (EIS) as part of agency review procedures prior to any "major action of state 
(federal) government significantly affecting the quality of the human

environment."

Agencies are directed to circulate these impact statements to other agencies and to the public for comment, and the EIS must "accompany the proposal through the existing agency review processes."

Fees

State agencies are authorized to assess fees from applicants for permits or licenses to help meet the costs of preparing EIS's on such permit applications. Such fees may be assessed only if the cost of preparing the EIS will

exceed $\$ 2,500$. The law sets a schedule of maximum fees based on the estimated cost of the project being reviewed. Unexpended fee monies are returned to the applicant. (The EIS fee rules does not apply to applications under the Major Facility Siting Act or the Water Use Act, because those laws contain separate fee provisions.)

State Use of Federal EIS's

Provisions in state EIS regulations authorize state agencies to adopt and incorporate by reference EIS's previously prepared by federal agencies on related projects. The state EIS then may take the form of an addendum to a pre-existing EIS. Joint state-federal teams may be formed to conduct joint reviews of projects that require both state and federal action.

\section{EIS Procedures}

State and federal EIS procedures are similar in overall approach although they differ in detail. Federal regulations vary from agency to agency. All state agencies with EIS responsibilities have adopted uniform regulations, which vary only in some of the fee provisions. 
When a proposed project is originated in an agency or presented to a permit authority by an applicant, a preliminary environmental review is carried out to determine whether the impact of the proposed action will be significant enough to require an environmental impact statement. If the review indicates a significant impact, the responsible officials must prepare a draft environmental impact statement.

State regulations require the agency to notify an applicant within 30 days after the application is filed if an EIS will be required. If so, the applicant will be asked for an estimate of the project's cost so that a fee can be assessed.

There are no uniformly applicable time limits for preparing a draft EIS, though specific state statutes impose overall time limits on agency review. When the EIS is completed, it is reviewed within the agency and then circulated to the public for review and comment. (State regulations allow 30 days for comment; federal regulations, 90 days. If public controversy or the nature of the proposed action make it appropriate, a public hearing may be held after adequate notice.

Following the comment period and hearing, a final EIS will be prepared, containing new or amended information and responses to issues raised during the comment period. State regulations provide that if no substantive comments are received and no new issues are raised, the draft ElS may serve as the final statement.

The typical geothermal development project may trigger EIS procedures at numerous stages, from leasing to development drilling to facility construction. Unless properly coordinated, separate EIS reviews could significantly lengthen the total review process. Some coordination of procedures is achieved under 
the Major Facility Siting Act, and the Environmental Protection Agency is developing a coordinated permit review procedure for air and water quality programs.

In order to avoid duplication in EIS procedures and to achieve maximum coordination among the agencies, the developer should, at an early stage, provide all agencies having permit authority with an advance summary of the proposed project. 


\section{UTILITY EASEMENTS}

Easements may be required across federal, state, local or private lands for developing or using geothermal resources (i.e., pipelines, electric transmission lines, etc.)

\section{a. Federal Lands}

If easements are required across federal lands for constructing utility or power lines, the local, district or area office of the appropriate land management agency should be contacted for application forms and other information. Application fees are assessed according to the length of the utility corridor. Annual compensation is determined by the fair market value of the interest in land being acquired. For BLM lands, contact the state office in Billings. For National Forest lands, contact the local district ranger. For Indian lands, contact the BIA superintendent of the appropriate tribal agency, or the BIA area office in Billings.

\section{b. State Lands}

The Board of Land Commissioners is authorized to grant easements across state lands for "public uses", which may include utility corridors. Applications (which must include extensive information about the land desired) are made to the Department of State Lands, which reports its findings to the Board of Land Commissioners. The Board fixes compensation and damages to be paid to the state. Compensation is based on the fair market value of the interest to be conveyed; damages are the actual damages to surrounding land. Negotiations must be held with any prior lessees of the land across which the easement is to run, and compensation paid for any harm to such prior leasehold interest. If the easement lies across state forest lands, initial application is to DNRC. 
For state recreation areas, wildlife refuges, game ranges, etc., application is made to the Department of Fish, Wildiife and Parks

\section{c. Local Government}

In addition to the leasing authority discussed elsewhere, city or town councils and boards of county commissioners have permit authority for laying water, gas, and sewer mains under sțreets, alleys, and roads. Electric and telephone public utilities are authorized to construct lines along public streets and roads. Lines in new service areas must be constructed underground if it is technically and economically feasible. City councils may regulate the erection of poles and cables within city limits. The National Electric Safety Code, promulgated by the U.S. Department of Commerce, applies to power lines, and the Public Service Commission is responsible for its enforcement.

\section{d. Highway Right-of-Way}

All public utilities and all common carrier pipelines have the authority to use public right-of-way, but proposals must be reviewed by the Department of Highways to achieve maximum public use of right-of-ways while protecting public safety and avoiding conflicts between utility needs and transportation needs. These regulations apply only to the federal aid highway systems and do not apply to utilities operated by local governments within city limits unless utility lines are proposed on federal aid right-of-ways. The Highway Department reviews utility proposals for comformity to minimum safety standards and for proper drainage, vegetation maintenance, debris control, traffic protection, and scenic enhancement.

Written approval must be obtained from the board of county commissioners, county road supervisor, or county surveyor for excavation or construction across public highways. 
The utility submits a notice of proposed right-of-way occupancy, including plans and location, to the appropriate field maintenance bureau chief. If the plans conform to the standards set forth in the regulations, the bureau chief will approve them. If not, he will return the plans with written comments. The utility may resubmit the corrected plans or appeal the decision to the Board of Highway Appeals.

\section{e. Private Lands and Eminent Domain}

If pipelines, transmission lines or other facilities for developing or using a geothermal resource must cross privately-owned lands, the geothermal developer must either negotiate with the landowner for the necessary easements, or seek to acquire such an easement by use of "eminent domain". Eminent domain is the right of the state - or other entities operating in the public interest to take private property for "public use". Public uses include constructing and maintaining pipelines that conduct water or heat for public consumption, flumes and pipelines used for "working mines" or for conducting "refuse matter from mines", electric power lines, and using the surface of land to extract "minerals" where the mineral rights and the surface are owned by different parties.

Clearly, transmitting geothermal heat or electric energy for public consumption qualifies as a public use. In order to use eminent domain, the developer must file a complaint in district court describing the proposed public use, the source of the right to such use, the property interest sought, and the present ownership. All parties with an interest in the land should be named as defendants. In their answers to the complaint, the defendants will indicate the amount of money they claim as just compensation for the proposed taking. The court must determine whether the proposed use is an authorized public use 
and establish the amount of property to be taken. After receiving a report from a court appointed panel, the court must also determine the appropriate compeñsation to be paid by the petitioner. 


\section{UTILITY REGULATION}

\section{a. Public Service Commission}

A "public utility" is an entity (individual, corporation, association, etc.) which owns or controls equipment or facilities in Montana used to produce or deliver, inter alia, heat, water or power to other entities. Thus, any geothermal system that supplies heat or energy to persons other than the owners of the geothermal system themselves would be a public utility subject to the jurisdiction of the Public Service Commission (PSC), except for Rural Electric Cooperatives.

The Montana PSC does not issue certificates of public convenience and necessity authorizing the construction and operation of a utility, as do public utility commissions in other states. That function is handled in part by the Board of Natural Resources and Conservation under the Major Facility Siting Act. The PSC, however, has extensive jurisdiction over the operations and activities of a utility once operations begin. Public utilities are required to provide reasonably adequate service at reasonable rates. Books and records must be made available to the PSC for inspection on request, and annual reports of operations are submitted to the PSC. All records and reports in the PSC's possession are available for inspection by the public.

Rates

Rate schedules must be filed with and approved by the PSC. The developer should consult in advance with the PSC staff in establishing an initial rate tariff in order to avoid later challenges. No changes in such rates may be made without approval of the PSC. In setting rates, the PSC takes into account 
the expenses and capital of the utility, and may ascertain the value of the utility's property as well.

Business Activities

The PSC may investigate all aspects of the management of a public utility's business. The utility must apply to the PSC for permission to issue or acquire securities. Such permission will be granted unless 1) it would be inconsistent with the public interest, 2) it would be for a purpose not permitted by the law, or 3) the aggregate amount of securities outstanding and proposed would exceed the fair market value of the utility's property. Notes of obligation for a term of no more than one year and for a principal amount of no more than five percent of the utility's outstanding securities may be issued without PSC approval .

Investigations

Either on its own motion or on filing a complaint alleging unfair, discriminatory, or unreasonable rates, inadequate service, or unreasonably rules or procedures, the PSC may conduct an investigation and hold a formal hearing after which it may issue orders adjusting rates, procedures, or service.

Utilities are obligated to report all serious accidents which occur in the operation of a public utility; the PSC then must investigate them.

In exchange for the regulatory burdens imposed on them, public utilities are given eminent domain powers and are authorized to build pipelines and transmission lines along public roads. Electric utilities are protected from competition by the provisions of the Territorial Integrity Act. 


\section{b. Utility Associations}

The characteristic of a utility that makes it "public" and therefore subject to the jurisdiction and regulation of the PSC is that service is offered to the "public", i.e., to persons other than the owners of the facility. The developer of a small-scale, local geothermal heating system designed to serve only a few customers in a small area may avoid PSC jurisdiction by forming a cooperative association in which the customers are members of the association, and the association owns the geothermal system.

The law authorizing cooperative associations is general in application, not designed specifically for utility service. From three to seven persons may form an association by filing articles of incorporation with the Secretary of State. A $\$ 20$ filing fee is required. The association may begin operations when it has ten members. Each member has one share of stock and equal voice in governing the association.

Since it is not a public utility, such an association would not have the benefit of eminent domain or the use of public right-of-way.

\section{c. Rural Electric Cooperatives}

To avoid PSC jurisdiction as well as certain tax burdens, five or more persons may form a rural electric cooperative, filing the necessary articles of incorporation with the Secretary of State. Such a cooperative may be established to supply electric energy and telephone service in rural areas (outside of towns with more than 3500 people, or in towns, at least 95 percent of whose electric and telephone service was supplied by cooperatives as of February 1, 1971). Cooperatives organized under this law are eligible for low-interest loans and other assistance under the federal Rural Electrification Act. 
Electric cooperatives are empowered to do all things necessary and proper for generating, purchasing, distributing and selling electric power. The cooperative's members are its customers. Excess revenues are distributed to the members at the end of the year as refunds, in proportion to the amount of patronage. The cooperative pays an annual fee to the state of $\$ 10$ for each 100 persons served, and is exempt from all other excise and income taxes. And the cooperative is exempt from the jurisdiction of the Public Service Commission.

Like a public utility, an electric cooperative is authorized to build lines and facilities along public roads and across public lands, and may exercise eminent domain powers for construction of electric lines. A cooperative may provide electric service to its members, to government agencies and political subdivisions of the state, and to other persons or entities; but the number of "general public" customers may be no more than 10 percent of the number of members of the cooperative. The cooperative may make loans to its customers or lease electrical and plumbing equipment and fixtures. No one who is not an incorporator of the cooperative may become a member unless he agrees to use electricity furnished by the cooperative when it is available.

In its present form, the rural cooperative law is available only for electric or telephone service. Geothermal heating systems or other alternative energy systems cannot take advantage of this form of organization. 


\section{TAXATION}

\section{a. Federal Taxation}

Geothermal wells are entitled to a depletion allowance as a deduction for federal income tax purposes according to the following schedule:

$\begin{array}{cc}\text { taxable year beginning: } & \frac{\%}{0} \text { of gross income } \\ 1980 & 22 \\ 1981 & 20 \\ 1982 & 18 \\ 1983 & 16 \\ 1984 \text { and thereafter } & 15 \\ & \end{array}$
are allowed for rental and royalty payments. The depletion allowance may not exceed 50 percent of taxable income. Deductions from income are also allowed for intangible drilling costs and other development expenditures. The treatment is similar to that for oil and gas wells.

\section{b. State Property Tax}

Tax treatment of geothermal resources will depend on whether they are considered "minerals" for the purpose of the tax laws. This question has not been resolved in Montana, but it is likely that geothermal resources will be treated as "miscellaneous minerals".

If so, the net proceeds of a geothermal well will be assessed at 100 percent of market value. To determine net proceeds, the gross value at the well-head of geothermal energy and by-products will be calculated. Allowable expenses (royalties, labor, equipment, supplies, operations, repairs, etc., and a 6 percent depreciation allowance) will be deducted from gross yield to get net proceeds. 
The operator must submit annual reports to the Department of Revenue by March 31 , stating gross yields and costs. After assessing net proceeds, the Department will transmit such assessments to the appropriate county for entering on the tax rolls. The county mill levy. will then apply. In addition to net proceeds, all mining equipment is assessed at 11 percent of market value.

Property of rural electric cooperatives is assessed at 3 percent of market value; property of (non-electric) public utilities is assessed at 15 percent; and property of electric power companies is assessed at 12 percent of value. If a cooperative or utility owns the geothermal well, then these assessment rates will supercede the rates given above for mine proceeds and equipment.

\section{c. State License Tax}

Corporations are subject to an annual 1 icense tax of $63 / 4$ percent of net income, with a minimum tax of $\$ 50$. Rural electric cooperatives are exempt from this tax. In addition, any producer of electric energy is subject to a special tax of $\$ .0002$ per kilowatt-hour of electric energy generated.

\section{d. New Industrial Property}

"New industrial property" is assessed at a special rate of 3 percent of narket value for the first three years of operation of the industrial facility. This treatment applies to "new eirdeavors," as opposed to mere expansion of existing plants. Application for treatment as new industrial property shuld be made to the Department of Reverue. No such property will qualify if the plant will have an adverse impact on existing state, county or municipal services. Local taxing authorities may waive their objections to the special tax treatment if the owner agrees to pre-pay property taxes during the construction period. 
III. FUNDING OPPORTUNITIES 


\section{PUBLIC FUNDING}

A number of public funding mechanisms may be avail lablie to enable local government units to assilst in financing geothermal projects. The applicability of thes: mechamilsms to geothermal development is not cliear in all cases, however. Possiblle funding devices are discussed briefly below, but geothermal developers who wilis to obtain public financing must contact the city or town councill or board of county commissioners for complete information.

\section{a. Improvement Districts.}

A Rural lmprovement District (RIID) may be established for such special improvements as may be petitioned for by the landowners in the proposed district. Presumably, this would include a geothermal district heating system. On petition of 60 percent of the landowners in the proposed district, the board of county commissioners is authorized to: adopt a resolution of intent to establish a district. The resolution will describe the boundaries of the district, the improvements to be finances, and the estimated cost. Notice of the resolution and of a public hearing is published in local papers and mailed to landowners in the proposed district.

Written protests will be received by the county commission for fifteen days and will be considered at the next regular meeting of the commission following the protest period. If written protests are received from owners of more than 50 percent of the property in the proposed district, no further action may be taken for six months.

When all protests have been heard and dealt with, the commission may pass a resolution establishing the district and ordering the improvements. The commission then invites bids on thework. Owners of 50 percent of the property. 
in the district may contract to do the work themselves. A landowner has sixty days after the contract is awarded to protest that faulty procedures in establishing the district or awarding the contract will cause him harm, or that his property will be damaged by the proposed project. If the protest is allowed and damages are awarded, they are paid out of the assessments as part of the cost of the project.

The costs of the project are paid by the sale of bonds after publication and notice. To repay the bonds, plus interest, and to raise operating and maintenance expenses, the properties within the RID are assessed in proportion to area or property value (but the latter method may be used only if the district lies more than five miles from the nearest town.) If the improvements are of more than local or ordinary benefit, or if the cost will exceed one-half of the taxable value of property in the district, the county commission may extend the district boundaries to include non-abutting properties for the purpose of assessment.

Once the size of the assessments is determined, the county commission adopts a resolution to levy a tax on the assessed property, and provides public notice and hearing for objections to the assessments. Assessments are added to the county tax rolls. They may be paid all at once or in installments (plus interest) over a period of not more than thirty years. The obligation to pay the assessment creates a lien on the assessed property.

Within cities and towns, the Special Improvement District (SID) is the analogous mechanism. Procedures are essentially the same as for the RID, with some variations (e.g., a petition of the landowners is not necessary. Generally, the potential developer should approach the city council and ask that a SID be established). 
It is not clear, however, that a geothermal heating system ils eligible for SID treatment. The law lists specific projects that may be financed through SID's, and "waterworks" comes the closest to a geothermal system. There is no catch-all phrase authorizing "other improvements"l as is the case for RIDS.

\section{b. General Obligation Bonds}

Cities and counties may issue general obligation bonds to raise funds for specified purposes. Such bonds create a debt on the public treasury and are repaid wi th property taxes. They must be approved by the voters at a general or special election.

This method of financing is available only for the purposes listed in the law. Geothermal development is not included, though municipalities may finance "waterworks", and "water rights for supplying the city or town with water." Furthermore, general obligation bonds are available only for publicly owned and operated facilities.

\section{c. Municipal Revenue Bonds}

A somewhat more versatile funding mechanism, the municipal revenue bond, is available to cities and towns. The bonds create a lien on the facility itself rather than on the general credit of the municipality. They are repaid through user fees rather than through property taxation, and they do not require voter approval.

It is again unclear, however, whether this mechanism is available for geothermal systems. Revenue bonds may be used to fund, inter alia, water systems and "other revenue-producing facilities and services authorized in these codes for cities and towns". Revenue bonds are available only for publicly owned and operated facilities. 


\section{d. Industrial Development Projects}

Perhaps the most flexible public funding mechanism is authorized by the Industrial Development Project Act. In essence, this law makes the credit of cities and counties available to private developers to assist in financing commercial, agricultural or industrial enterprises. The city or town council, or board of county commissioners, issues limited obligation revenue bonds for the construction or operation of the project, and then leases or sells the project to the private developer. In this way, the developer can take advantage of the tax-exempt status of municipal or county bonds. To qualify, the project must be found to be in the public interest. Unlike projects financed by general obligation or revenue bonds, projects financed under this law are in no way operated by the local government.

The law applies to, inter alia, "commercial, manufacturing, agricultural, or industrial enterprises." There is no reason why geothermal developments could not be included under this definition. 


\section{LOANS, GRANTS, AND TAX INCENTIVES}

\section{a. The Geothermal Loan Guarantee Program}

\section{Purpose}

The Geothermal Loan Guarantee Program is designed to stimulate commercial development of geothermal energy by minimizing the financial risk incurred by development capital lenders. Under this program, the United States government pledges its full faith and credit to the lender to guarantee the repayment of principal and interest on geothermal development loans. The objective is to provide financial incentives for the early and rapid development of geothermal alternatives, while helping to establish the resources and technologies necessary for a self-sustaining industry. As the industry develops, normal financial relations between borrowers and lenders will also develop, eliminating the need for this program.

\section{Funds Available}

Loan guaranties of up to 75 percent of the estimated cost of a project may be granted for up to 30 years. At least 25 percent of the project cost must be in borrower's equity. The maximum loan guaranty for a single project is set at $\$ 50,000,000$, with allowances for larger amounts for projects considered to be in the national interest. The maximum loan guaranty amount that any single borrower may have outstanding is $\$ 2,000,000$. The granting of a geothermal loan guaranty does not prohibit the borrower from qualifying for or obtaining other federal financial assistance.

\section{Eligibility}

The range of eligible projects is very broad. Any project that falls into one or more of the following categories is eligible for a loan guaranty. 
- Determination and evaluation of the commercial potential of geothermal resources.

-Research and development in geothermal extraction and utilization technologies.

-Obtaining rights to geothermal resources.

-Development, construction, and operation of equipment or facilities for the commercial production of electrical energy from geothermal resources.

-Development, construction, and operation of equipment or facilities for nonelectric application of geothermal resources.

Any organization, public or private, can be granted a geothermal loan guaranty. According to the program regulations, preferential consideration is given to projects that are to be carried out by small independently-owned and -operated businesses and small utilities. In addition, priority is given to projects that promise to produce geothermal applications quickly, projects that use new technological advances, and projects undertaken in new geothermal resource areas.

How to Apply

For additional information and for application forms for the Geothermal Loan Guarantee Program, contact:

Geothermal Loan Guarantee Office San Francisco Operations Office U.S. Department of Energy 1333 Broadway Oakland, CA 94612 415/273-7151

Time Frame

Normal evaluation and approval time have been established at approximately 4 months in the San Francisco DOE office and 2 months in the DOE Washington Headquarters. Applications may be submitted at any time during the year. 


\section{b. Program Research and Development Announcement (PRDA)}

\section{U.S. Department of Energy}

\section{Purpose}

The Progream Research and Development Announcement (PRDA) granting system is designed to provide an opportunity to interested parties to propose engineering and feasibility studies in energy-related areas. Several of these PRDAs have been specifically issued for geothermal projects. The last geothermal PRDA was issued in 1979, for studies covering a detailed analysis of engineering, economic and institutional factors associated with uses of geothermal heat.

\section{Funds Available}

Past PRDA announcements have awarded from six to twelve grants per proposal. Most of the projects have received less than $\$ 125,000$. Under the last PRDA notice, $\$ 124,995$ was awarded to an engineering firm to do an engineering and economic study of geothermal heating applications for the Fort Peck Indian Reservation.

\section{Eligibility}

Proposals may be submitted under this program by individuals, non-profit organizations, educational institutions, and companies that either own the geothermal resource area in question or can gain access from the owners of the resource.

\section{How to Apply}

The Department of Energy mails out notices of upcoming PRDAs periodically, usually about once a year. These PRDAs are not necessarily aimed at geothermal 
development, since any energy related area may be covered in a PRDA. In order to receive notice of these PRDA mailings, write to:

\author{
Idaho Operations Office \\ U. S. Department of Energy \\ Geothermal Program \\ 550 Second Street \\ Idaho Falls, ID 83401 \\ c. Program Opportunity Notice (PON) \\ U.S. Department of Energy
}

\title{
Purpose and Background
}

In September 1977 and April 1978, the Department of Energy (DOE), Division of Geothermal Energy, issued a document indicating DOE's desire to receive and consider for partial support proposals for direct heat utilization or combined electric/direct heat utilization field experiments demonstrating single or multiple usages of geothermal energy. This document was issued under the title, "Program Opportunity Notice - Direct Utilization of Geothermal Energy Resources - Field Experiments." Although Program Opportunity Notice (PON) is the name of this offering document, it has become common practice to call any program resulting from these notices a PON.

These solicitations are part of DOE's national geothermal energy program plan, of which the goal is commercial development of hydrothermal resources by the private sector, for direct use purposes. Encouragement is being given to the private sector by DOE's cost-sharing a significant portion of the front-end financial risk in certain field experiments, DOE encourages private development.

DOE's primary interest under these PON's was to encourage field experiments in space/water heating and cooling for residential and commercial buildings, agricultural and aquacultural uses, and industrial processing. 


\section{Funds Available}

Under the last PON, 15 proposals were selected for funding. The government is not obligated to make any particular number of awards, nor is it obligated to award any particular aggregate sum. One of the 15 proposals funded was from the Montana Energy and MHD Research and Development Institute, Inc. (MERDI), Butte, Montana, to design, construct, and operate a geothermal conversion system for space heating at Warm Springs State Hospital in Montana. A cooperative agreement was signed between DOE and MERDI in March, 1979.

\section{Eligibility}

Individuals, corporations, educational and other instituions, and state and local agencies were eligible under the last PON. Federal agencies, government laboratories and other government facilities were not eligible. Eligibility may vary from PON to PON. All grants are awarded on a cost-shared basis.

How to Apply

PON notices are released sporadically. It is therefore necessary to get on the DOE mailing list to receive the PON notices as they are announced. To get on the mailing list, write:

$$
\begin{aligned}
& \text { U.S. Department of Energy } \\
& \text { San Francisco Operations office } \\
& 1333 \text { Broadway } \\
& \text { Oakland, CA } 94612 \\
& \text { d. Appropriate Technology Small Grants } \\
& \text { U.S. Department of Energy }
\end{aligned}
$$

\section{Purpose}

This program is designed to encourage development, demonstration and dissemination of information concerning energy related systems and supporting 
technologies. The program goals include applying existing technologies to new and innovative uses, encouraging the use of renewable resources such as geothermal, wind, and solar energy, and encouraging the conservation of fossil fuels.

Funds Available

Grants up to $\$ 50,000$ are available for project development and demonstration, with the average grantee receiving $\$ 12,000$. Between $\$ 300,000$ and $\$ 500,000$ will be available in 1981 to the six-state region that includes Montana. During 1979, 540 proposals were submitted, of which 30 were funded. The number of funded proposals in 1980 is unknown at this writing, but over 900 were submitted. Of the 1979 proposals, 3 percent dealt with geothermal projects, and one funded project involved a geothermal heat exchanger for a Durango, Colorado school.

\section{Eligibility}

Individuals, local non-profit organizations and institutions, state and local agencies, small businesses, and Indian tribes are eligible to submit grant applications.

\section{Time Frame}

Application forms for the 1981 granting period will be available in January 1981, and must be returned by March 1981. Grant recipients will be notified within four months of the deadline for grant submittals.

How to Apply.

To receive a copy of the 1981 grant application, contact: 


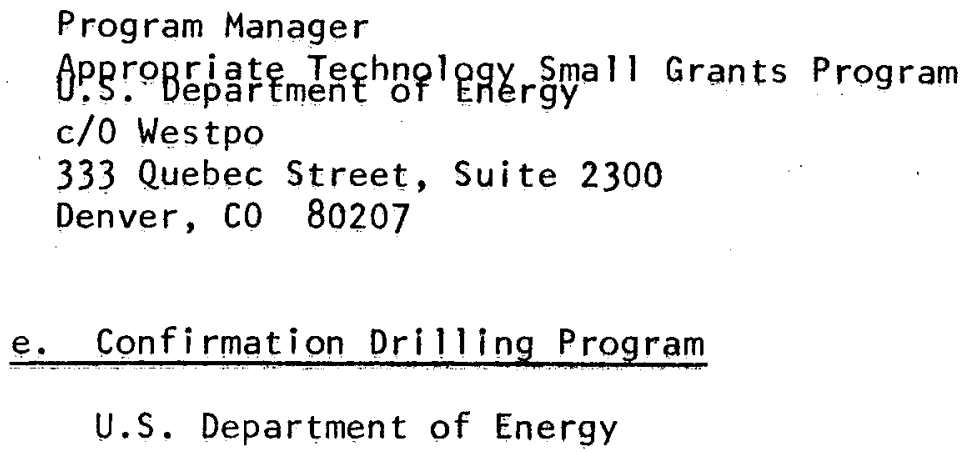

\section{Purpose}

The U.S. Department of Energy sponsors a program to share drilling costs associated with confirming a geothermal reservoir for direct use applications. Confirmation of reservoir temperatures, flow rates and longevity are often high-cost and high-risk ventures. This program is designed to stimulate the direct use of geothermal energy by reducing the economic risks associated with confirmation.

\section{Funds Avai lable}

The federal percentage share of costs will be determined by a negotiated formula between the developer and the government. This formula is based on the degree of success in confirming an economically usable resource. If the drilling project is completely successful, the Department of Energy's cost share will be about 10 percent; for a completely unsuccessful project (no usable resource is found), the Department of Energy's cost share will be about 90 percent. Most cost shares will range between these two extremes.

The total amount of funding available under this program is approximately $\$ 10,000,000$ in 1980 and $\$ 20,000,000$ in 1981 .

\section{Eligibility}

Private individuals, private companies, state and local government agencies are eligible under this program. 
How to Apply

A competitive procurement announcement will be released once a year.

This announcement can be received by writing or by calling:

Susan Prestwich
Idaho Operations office
Department of Energy
550 2nd Street
Idaho Falls, ID 83401
$208 / 526-1146$

The application must include the following information:

1) Good geological evidence for the existence of the resource.

2) The final use of any geothermal fluids discovered.

3) An adequate outline of the exploration, drilling and flow testing program.

4) An acceptable cost sharing plan.

\section{Time Frame}

The first applications under this program will be released in May of 1980 , and applications will be due within 60 days of the announcement. Successful applicants will receive government cost share approvals beginning in october 1980.

\section{f. Alcohol Fuels Program}

Geothermal energy can be used in several stages of alcohol production, including distillation, mash drying and space heating. Funding for the development of alcohol fuels is available from several federal agencies, including the Department of Energy, the Small Business Administration, the Department of Agriculture, and the Department of Housing and Urban Development.

The U.S. National Alcohol Fuels Commission, established in 1978 to further alcohol fuel development, has prepared a compendium of all the federal funding sources that can be used by a geothermal developer who is interested in alcohol production facilities. 


\section{Eligibility}

Varies from program to program.

Funds Available

Varies from program to program.

How to Apply

To receive the compendium, write to:

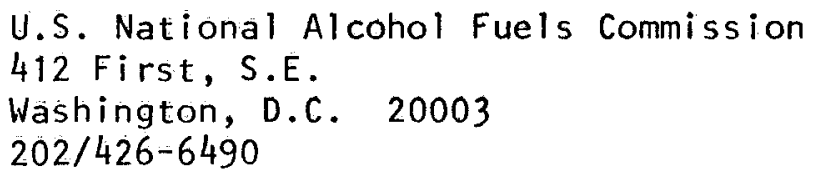

Ask för the Federal Agèncy Compendium of Alcohol Fuels Programs, March 1980.

\section{g. Old West Regional Commission Grants}

\section{Purpose}

The 0ld West Regional Commission, consisting of the Governors of the stàtès of Montaná, North Dakota, Nebraska, South Dakota and Wyoming, was organiżed to provide leadership to the states in coping with the region's economic problems. The Commission's major objectives include increasing per cápita përsonal income, achieving environmental quality goals, and increasing citizen participation in government.

One method used in achieving these goals is to provide grants for research, development and demonstration projects directed to solving economic problems of the region.

Several geothermal energy projects have applied for funding through this organization. The Jefferson County Commission has received a $\$ 20,000$ grant to study the potential for using geothermal energy for industrial and space heating during the summer of 1980 . 
Funds Available

Project funding varies widely, with awards ranging from $\$ 10,000$ to over $\$ 1,000,000$.

Eligibility

State agencies or institutions, private organizations, committees or firms may apply for funding.

Time Frame

Proposals may be submitted to the Commission Alternate for Montana at any time during the year.

How to Apply

Proposals for funding and requests for further information should be submitted to:

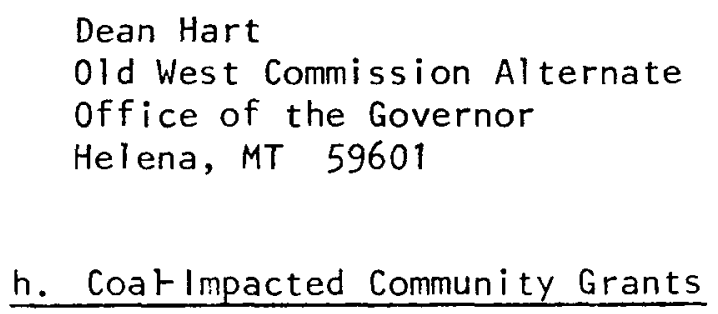

Purpose

This program is designed to assist local governmental units forced to expand their public services by large-scale development of coal mines and coal-using energy complexes. The project is funded from the severance tax levied on all coal mined in eastern Montana. No geothermal energy projects have applied for a grant under this program, but such projects as geothermal heating of city, county or state buildings may be eligible. 


\section{Eligibility}

Communities with an increase or expected increase in estimated population of at least 10 percent during any three years since 1972 , due to coal development, are eligible for funding under this program. The governing body of a city, town, county or a school district may apply, as may any other local or state governmental unit or agency that needs financial support to enable .

it to provide services needed as a direct consequence of coal development. Communities in Big Horn, McCone, Treasure, Rosebud, Yellowstone, and Dawson counties have received grants.

\section{Funds Available}

Grants totaling 18 million dollars have been awarded since the inception of the program in 1976. Most of these grants were under $\$ 200,000$, although five projects have been awarded grants worth over one million dollars each.

\section{How to Apply}

Applications for coal impact grants may be received from:

$$
\begin{aligned}
& \text { Montana Coal Board } \\
& 1426-9 \text { th Avenue } \\
& \text { Helena, MT } 59601 \\
& 406 / 449-2400
\end{aligned}
$$

The application must describe the nature of the proposed project, its cost, and the time involved.

Time Frame

Grants are awarded within 6 months after receipt of the application by the Coal Board. 


\section{i. Alternative Renewable Energy Sources Program}

\section{Montana Department of Natural Resources and Conservation}

\section{Purpose}

The Alternative Renewable Energy Sources Program was authorized by the Montana Legislature in 1975 to assist the state in lessening its reliance on conventional energy sources. The Legislature authorized 5 percent of the state coal severence tax to be used for grants to projects conducted within the state of Montana and applicable to the state's energy needs. The grants are awarded to projects that research, develop or demonstrate such renewable energy sources as geothermal, solar, wind, water and biomass.

Funds Available

During the three years of the program's existence, approximately 155 projects have been funded, receiving $\$ 2.3 \mathrm{million}$ dollars, or an average of $\$ 12,000$ per project. Nine of these projects have involved geothermal energy, receiving a total of $\$ 144,765$. There is no minimum or maximum allowable request, but applications for more than $\$ 100,000$ are discouraged. Examples of funded geothermal projects include a feasibility study using geothermal energy to heat the Warm Springs State Hospital, installation of a geothermal heating system at a private residence near Helena, and a geothermally heated bank in White Sulphur Springs.

\section{Eligibility}

With the exception of Department of Natural Resources employees or their relations, and religious organizations, any Montana individual is eligible to apply for a grant. "Individual" includes corporations, partnerships, educationals and scientific institutions, trusts and foundations, business entities and governmental units. All projects must be carried out in Montana. 
How to Apply

The submittal period for unsolicited grants is from August 1 to October 1 of each year. The Department of Natural Resources and Conservation may, from time to time solicit specific proposals in order to initiate projects needed to meet progràm óbjectives. Grant application guidelines and reports on past projects are available at public libraries throughout the state. For further information on this program, contact:

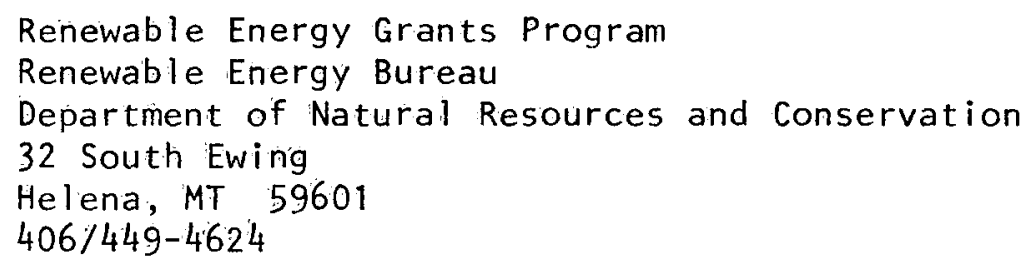

\section{j. Institutional Buildings Grants}

Montana Department of Natural Resources and Conservation

Under the National Energy Conservation Policy Act of 1978, financial assistance is available for conducting energy audits, analyzing costs, and determinirig payback periods and renewable energy potentilals for energy conservation meàsures in schools, hospitals and local government buildings. Geothermal energy retrofits are classified as renewable energy resources under this program, which is administered by DNRC.

The federal share of the cost of all the activities funded under this program will be at least 50 percent, with the remainder comilng from non-fiederal souirces.

The program consists of the following four steps, which must be performed sequentially.

1) Preliminary energy audit - The applicant fitls out a preliminary energy audit form, indicating annual energy consumption and type of fuel used, and describing the building characteristitics. 
2) Energy audit - A brief analysis of building characteristics, including energy consumption levels, recommended operating and maintenance changes, and an initial assessment of the building's potential for using renewable energy. Up to 50 percent of this audit may be funded under this program, on a non-competitive basis, provided a contract with DNRC is first arranged. Only qualified energy auditors may conduct this audit.

Phase 11

3) Technical Assistance Program: A detailed professional analysis of the building will be conducted to determine its potential for conserving energy and converting to geothermal or other renewable energy sources.

4) Energy Conservation Measures: Financial assistance will be offered only to schools and hospitals that successfully complete the above three steps. The funds will be used to purchase and install energy conservation materials or renewable energy equipment.

\section{Funds Available}

Approximately $\$ 700,000$ was awarded to 53 different applicants in Montana during the last awards cycle. The program, which runs through 1981, will have two more granting cycles: one in June, 1980, and one in February, 1981. Notice of grant awards will be made within two months of the granting cycle deadlines.

\section{Eligibility}

Public and non-profit schools, hospitals, local government buildings and public care facilities which were constructed and issued an occupancy permit 
before April 10, 1977 are eligible. Indian tribes are allso eligible under this program, if the building in question is owned by the tribe.

How to Apply

To receive the preliminary audit form and other information, contact:

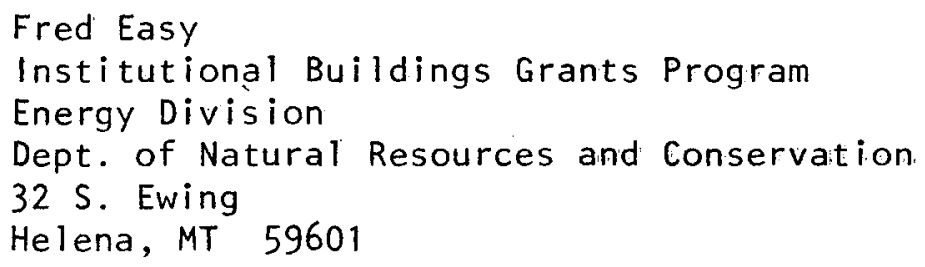

k. Tax Incentives

Federal

Credit against income tax is allowed for expenditures for equipment used to produce, distribute or use geothermal energy. Public utility property is not included in this treatment.

A residential energy credit is allowed against the income tax of an individual taxpayer for expenditures for installing a geothermal system in a principal residence. The credit is 30 percent of the first $\$ 2000$ and 20 percent of the next $\$ 8000$.

State

Montana will allow a tax credit of 10 percent of the first $\$ 1000$ and 5 percent of the next $\$ 3000$ spent for installing a "recognized non-fossil form of energy generation" in an individual taxpayer's principal residence, if installation is completed before December 31,1982 . These credits are available in half these amounts if federal tax credits (see below) are also applied. 
A deduction from gross income is allowed for a capital investment in a building for energy conservation purposes, defined as reducing energy waste or dissipation or reducing the amount of energy required to accomplish a given amount of work. This deduction does not apply to investments for installing a non-fossil form of energy generation.

Expenditures for installing a non-fossil form of energy generation are exempted from property-tax assessment for ten years after installation. These exemptions are 1 imited to $\$ 20,000$ for single-family residences and $\$ 100,000$ for a multi-family or non-residential building.

According to the Director of the Montana Department of Revenue, geothermal projects qualify as a "recognized non-fossil form of energy generation." Application for special tax treatments should be made to the Department of Revenue, Property Tax Division. 
FEDERAL AGENCIES

Bureau of Land Management, Department of the Interior

District office

Lands and Minerals Section

222 N. 32d Street

P.0. Box 30157

Billings, MT 59107

(406) $657-6291$

Bureau of Indian Affairs, Department of the Interior

Contact local BIA agency office or tribal council, or

Area office

Division of Resources

316 N. 26th Street

Billings, MT 59101

(406) $657-6387$

U.S. Geological Survey, Department of the Interior Geothermal Supervisor

345 Middlefield Road, Mail Stop 92

Menlo Park, California 94025

(415) 323-8111, ext. 2845

National Forest Service, Department of Agriculture Contact local district ranger

Army Corps of Engineers, Department of the Army

Missouri River Division

Box 103 Downtown Station

Omaha, Nebraska 68108

(402) 221-3001

North Pacific Division

Room 210 Courthouse

Portland, Oregon 97209

(503) 221-3700

Omaha District

6014 U.S. Post office \& Courthouse

Seattle District

Box c-3755

215 N. 17th

Omaha, Nebraska 68102

Seattle, Washington 98124

(402) 221-3900

(206) 764-3969

Environmental Protection Agency

Region VIII

Suite 900

1860 Lincoln Street

Denver, Colorado 80203

(303) 837-3895 


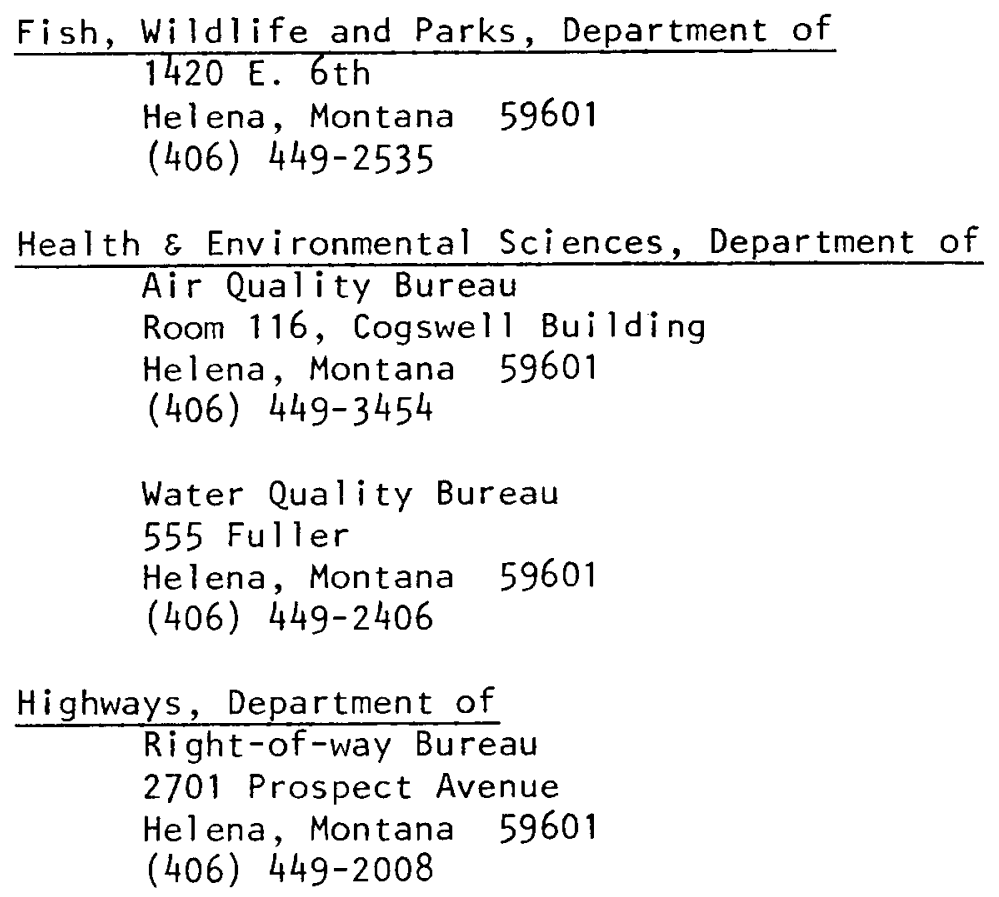

Health \& Environmental Sciences, Department of

Air Quality Bureau

Room 116, Cogswell Building

Helena, Montana 59601

(406) 449-3454

Water Quality Bureau

555 Fuller

Helena, Montana 59601

(406) 449-2406

Highways, Department of

Right-of-way Bureau

2701 Prospect Avenue

Hel ena, Montana 59601

(406) 449-2008

Natural Resources $\varepsilon$ Conservation, Department of

Water Resources Division

32 s. Ewing

Helena, Montana 59601

(406) 449-2872

Facility Siting Division

25 S. Ewing

Helena, Montana 59601

(406) 449-4600

Forestry Division

2705 Spurgin Road

Missoula, Montana

(406) $728-4300$

Public Service Regulation, Department of

Utility Division

1227 Eleventh Avenue

Helena, Montana 59601

(406) 449-2659

Revenue, Department of

Property Tax Division

Room 418 Mitchell Building

Helena, Montana 59601

(406) $449-2808$ 
Secretary of State

Room 202 Capitol Building

Helena, Montana 59601

(406) 449-2034

State Lands, Department of

Mineral Lease Bureau

1625 Eleventh Avenue

Helena, Montana 59601

(406) 449-2074

Surface Lease Bureau

1625 Eleventh Avenue

Helena, Montana 59601

(406) 449-2074 
LEGAL CITATIONS

\section{Part II STATUTES AND REgULATIONS}

\section{RESOURCE OWNERSHIP}

Geothermal resources treated as minerals: 77-4-105 M.C.A.;

30 U.S.C. 1024

Precedent: U.S. Vs Union 0 il of California, 549 F.2d 1271 (9th Circ) Definition of geothermal resources in Montana law: 77-4-102(1) M.C.A. Definition of geothermal resource in federal law: 30 U.S.C. 1001 (c) Montana Water Use Act: 85-2-102(14) M.C.A.

\section{LAND LEASING}

a. Federal Lands

Geothermal Steam Act of 1970: 30 U.S.C. 1001 et seq. BLM regulations

for geothermal lease administration are at 43 C.F.R. Part 3200 ;

U.S.G.S. regulations are at 30 C.F.R. Part 270.

Known Geothermal Resource Areas: 30 U.S.C. 1001 (e); 43 C.F.R. $3200.0-5(k)$

Qualifications of lessees: 43 C.F.R. 3202

Lease terms: 43 C.F.R. 3203 through 3206

b. Indian Lands

Leasing regulations for Indian lands; 25 C.F.R. Parts 131, 171, 172,173

c. State Lands

Authority of city council to grant leases: 7-8-4201 M.C.A.

Authority of county commission to grant leases: 7-8-2231 M.C.A.

\section{EXPLORATION AND DEVELOPMENT}

a. Federal Lands

Pre-lease exploration: 43 C.F.R. 3209

Operations under lease: 30 C.F.R. 270.30 et seq.

b. State Lands

No exploration until lease granted: A.R.M. 26-2.6(2)-\$60120

Operations under lease: A.R.M. 26-2.6(2)-\$50130

c. Seismic Exploration

82-1-101 et seq. M.C.A.; Regulations at A.R.M. 36-3.18(18) S10620 et seq. 


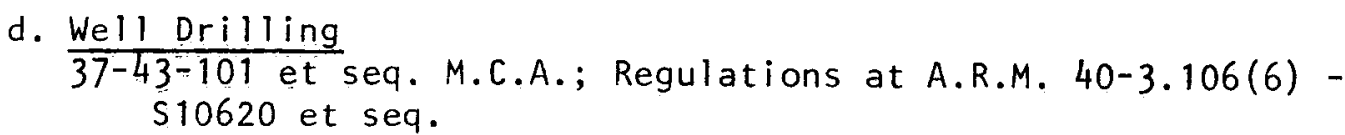

e. Water Use Permit

Provisions of the Montana Water Use Act: 85-2-101 et seq. M.C.A.

Regulations at A.R.M. 36-2.14J(1) - SS1400 et seq.

Ground water regulations: $85-2-501$ et seq. M.C.A.

4. LAND USE REGULATIONS

a. Zoning

Authority for cities and towns to restrict land use activities: 76-2-301 et seq.M.C.A.

Authority for county governments to restrict land use activities: 76-2-201 et seq. M.C.A.

Special zoning districts in unincorporated areas: 76-2-101 et seq. M.C.A.

b. Floodways and Floodplains

Land use restrictions for floodways and floodplains: 76-5-101 et seq. M.C.A.; Regulations at A.R.M. 36-2.14B(1) - $\$ 1400$ et seq.

c. Lakeshores

Land use restrictions for activities within 20 feet of the high water mark: 75-7-201 et seq. M.C.A.

d. Streams and Streambeds

Montana Streambed Preservation Act: 75-7-101 et seq. M.C.A.

Army Corps of Engineers authority to require permits: 33 U.S.C. 401 et seq.; 33 U.S.C. 1344

e. Erosion Control

Soil Conservation District authority to regulate land use:

76-15-701 et seq. M.C.A.

f. Open Space and Natural Areas

Authority for local conservation easements: 76-6-101 et seq.; 76-6-201 et seq. M.C.A.

Authority for state designation of "natural area": 76-12-101

et seq. M.C.A.

g. Forests

Regulation of slash disposal: 76-13-101 et seq.; 76-13-401 et seq.

M.C.A. Regulations at A.R.M. 36-2-10B(2)-S1060 et seq. 


\section{FACILITY SITING}

a. The Montana Major Facility Siting Act

Provisions of the act: 75-20-101 et seq. M.C.A. Regulations at A.R.M. 36-2.8(1)-S800 et seq.

Long-range plans: $75-20-501$ et seq. M.C.A.; Regulations at A.R.M. $36-2.8(6)-5860,870$.

Notice of intent: 75-20-214 M.C.A. Regulations at A.R.M. $36-2.8(4)-5854$ et seq.

Application for permit to build major facility: Regulations at A.R.M. 36-2.8(2)-S810 et seq.

Priority of Major Facility Siting Act: 75-20-401 M.C.A.

b. Electric Generation on Federal Lands

Licensing requirements for power plants on federal land: 43 C.F.R. 3250

\section{ENVIRONMENTAL PROTECTION}

a. Air Pollution Discharge Permit

Pre-construction review of new air pollution sources: 75-2-101

et seq. M.C.A. Regulations at 16-2.14(1)-51400 et seq.

Prevention of significant deterioration of air quality:

40 C.F.R. 52.21

b. Water Pollution Discharge Permit

Pre-treatment standards for wastewater discharged into municipal sewer systems: 40 C.F.R. Parts 128, 403

Permit requirements for discharges into state waters: 75-5-101 et seq. M.C.A. Regulations at A.R.M. 16-2.14(10)-S14460 et seq.

c. Underground Injection Control

Standards for geothermal injection well permits: 40 C.F.R. Parts $122,123,124,146 ; 44$ Fed Reg 34267 et seq. $(6 / 14 / 79)$ and 44 Fed Reg 23738 et seq. (5/20/79)

d. Environmental Impact Statements

Montana Environmental Policy Act: 75-1-101 et seq. M.C.A. National Environmental Policy Act: 42 U.S.C. 4321 et seq.

\section{UTILITY EASEMENTS}

a. Federal Lands

Application procedures: BLM lands - 43 C.F.R. 2800 et seq.; National Forest - 36 C.F.R. 251.50 et seq.; 23 C.F.R. 161 et seq.

b. State Lands

Board of Land Commissioners authority to grant easements: 77-2-101 et seq. M.C.A. 
c. Local Agencies

City council and county commission authority to grant permits for pipelines and power lines: 7-13-4101 et seq., 7-13-2101 et seq. M.C.A.

Authority of public utilities to build power lines: 69-4-101 et seq. M.C.A.

d. Highway Right-of-Way

Authority of Highway Department to review pipeline and power line proposals: A.R.M. 18-2.6 AI (6) $-\$ 6080$ et seq.

e. Private Lands and Eminent Domain

Acquiring easements by eminent domain: 70-30-101 et seq. M.C.A.

8. UTILITY REGULATION

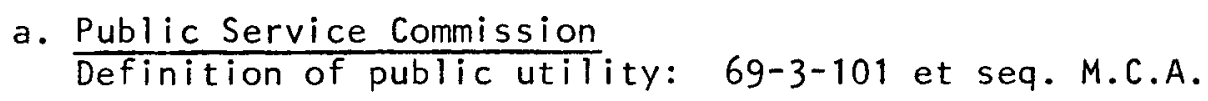

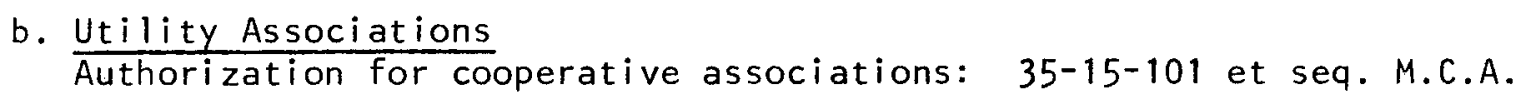
c. Rural Electric Cooperatives
Formation of rural electric cooperatives: $35-18-101$ et seq. M.C.A.

9. TAXATION
a. Federal Taxation
Depletion allowances: IRC Sec. 613(e)
Deductions from income: IRC Sec. 616
b. State Taxation
Assessment of geothermal resources: 15-6-131; 15-23-501 et seq.; 15-6-138 M.C.A.

Assessment of rural electric cooperatives: 15-6-135 M.C.A.

Assessment of public utilities: 15-6-141 M.C.A.

c. State License Tax

Annual license tax for corporations: 15-31-101 et seq. M.C.A.

Special tax for producers of electricity: 15-51-101 et seq. M.C.A.

d. New Industrial Property
Special tax rate for the first three years of operation:
$15-6-135 ; 15-6-152$ M.C.A. 
Part III. FUNDING OPPORTUNITIES

1. PUBLIC FUNDING
a. Improvement Districts
Method of establishing Rural Improvement Districts: 7-12-2101 et seq. M.C.A.
Method of establishing Special Improvement Districts: 7-12-4101 et seq. M.C.A.

b. General Obligation Bonds and
c. Municipal Revenue Bonds
Authority of cities and towns to issue bonds: 7-7-4101 et seq.; 7-7-2201 et seq. M.C.A.

d. Industrial Development Projects

Montana Industrial Development Project Act: 90-5-101 et seq. M.C.A.

2. LOANS, GRANTS AND TAX INCENTIVES

a. Tax Incentives

Federal income tax credit for expenditures: 26 U.S.C. 48(1) (2) (3)

Residential energy credit: 26 U.S.C. $44 \mathrm{C}$

Deduction from state tax for energy conservation: 15-32-101 et seq. M.C.A.

State income tax credit for non-fossil form of energy generation: 15-32-201 et seq. M.C.A.

Exemption of non-fossil energy generation from property-tax assessment: $16-2-201(3)$ M.C.A. 